\title{
Sensitivity of transatlantic dust transport to chemical aging and related atmospheric processes
}

\author{
Mohamed Abdelkader ${ }^{1,5}$, Swen Metzger ${ }^{1,2,3}$, Benedikt Steil ${ }^{1}$, Klaus Klingmïller ${ }^{1}$, Holger Tost $^{4}$, Andrea Pozzer ${ }^{1}$, \\ Georgiy Stenchikov $^{5}$, Leonard Barrie ${ }^{6}$, and Jos Lelieveld ${ }^{1,2}$ \\ ${ }^{1}$ Air Chemistry Department, Max Planck Institute for Chemistry, Mainz, Germany \\ ${ }^{2}$ Energy, Environment and Water Research Center, The Cyprus Institute, Nicosia, Cyprus \\ ${ }^{3}$ Eco-Serve, Freiburg, Germany \\ ${ }^{4}$ Institute for Atmospheric Physics, Johannes Gutenberg University of Mainz, Mainz, Germany \\ ${ }^{5}$ Division of Physical Sciences and Engineering, King Abdullah University of Science and Technology, Saudi Arabia \\ ${ }^{6}$ Department of Geological Sciences, Stockholm University, Stockholm, Sweden
}

Correspondence to: Mohamed Abdelkader (m.abdelkader@mpic.de) and Swen Metzger (s.metzger@cyi.ac.cy)

Received: 2 June 2016 - Discussion started: 4 July 2016

Revised: 30 January 2017 - Accepted: 17 February 2017 - Published: 20 March 2017

\begin{abstract}
We present a sensitivity study on transatlantic dust transport, a process which has many implications for the atmosphere, the ocean and the climate. We investigate the impact of key processes that control the dust outflow, i.e., the emission flux, convection schemes and the chemical aging of mineral dust, by using the EMAC model following Abdelkader et al. (2015). To characterize the dust outflow over the Atlantic Ocean, we distinguish two geographic zones: (i) dust interactions within the Intertropical Convergence Zone (ITCZ), or the dust-ITCZ interaction zone (DIZ), and (ii) the adjacent dust transport over the Atlantic Ocean (DTA) zone. In the latter zone, the dust loading shows a steep and linear gradient westward over the Atlantic Ocean since particle sedimentation is the dominant removal process, whereas in the DIZ zone aerosol-cloud interactions, wet deposition and scavenging processes determine the extent of the dust outflow. Generally, the EMAC simulated dust compares well with CALIPSO observations; however, our reference model configuration tends to overestimate the dust extinction at a lower elevation and underestimates it at a higher elevation. The aerosol optical depth (AOD) over the Caribbean responds to the dust emission flux only when the emitted dust mass is significantly increased over the source region in Africa by a factor of 10 . These findings point to the dominant role of dust removal (especially wet deposition) in transatlantic dust transport. Experiments with different convection schemes have indeed revealed that the transatlantic
\end{abstract}

dust transport is more sensitive to the convection scheme than to the dust emission flux parameterization.

To study the impact of dust chemical aging, we focus on a major dust outflow in July 2009. We use the calcium cation as a proxy for the overall chemical reactive dust fraction and consider the uptake of major inorganic acids (i.e., $\mathrm{H}_{2} \mathrm{SO}_{4}$, $\mathrm{HNO}_{3}$ and $\left.\mathrm{HCl}\right)$ and their anions, i.e., sulfate $\left(\mathrm{SO}_{4}^{2-}\right)$, bisulfate $\left(\mathrm{HSO}_{4}^{-}\right)$, nitrate $\left(\mathrm{NO}_{3}^{-}\right)$and chloride $\left(\mathrm{Cl}^{-}\right)$, on the surface of mineral particles. The subsequent neutralization reactions with the calcium cation form various salt compounds that cause the uptake of water vapor from the atmosphere, i.e., through the chemical aging of dust particles leading to an increase of 0.15 in the AOD under subsaturated conditions (July 2009 monthly mean). As a result of the radiative feedback on surface winds, dust emissions increased regionally. On the other hand, the aged dust particles, compared to the non-aged particles, are more efficiently removed by both wet and dry deposition due to the increased hygroscopicity and particle size (mainly due to water uptake). The enhanced removal of aged particles decreases the dust burden and lifetime, which indirectly reduces the dust AOD by 0.05 (monthly mean). Both processes can be significant (major dust outflow, July 2009), but the net effect depends on the region and level of dust chemical aging. 


\section{Introduction}

In the past several decades, transatlantic dust transport has gained tremendous attention because of many important impacts on Earth's climate, human health and ecosystems. Northern African dust transport over the Atlantic Ocean has emerged as a major contributor to the soil nutrient input to many islands in the Caribbean, the Bahamas (Muhs et al., 2007), Bermuda (Muhs et al., 2012) and in the Amazon basin (Bristow et al., 2010; Ben-Ami et al., 2012; Abouchami et al., 2013). Dust deposition influences the oceanic and terrestrial biogeochemistry through the transport of nutrients, such as iron (Ussher et al., 2013; Baker et al., 2013, 2010; Jickells et al., 2005) and phosphorus (Nenes et al., 2011), that dissolve into the ocean water. The emission, transport and deposition processes of the northern African dust are strongly influenced by meteorology, causing strong seasonal, interannual, and decadal variability (Mahowald, 2007; Mahowald et al., 2010). Large fractions of the dust emissions are carried across the western coast of northern Africa up to the western Atlantic (Prospero et al., 2014), and significant correlations exist between the dust and climate variables, such as sea surface temperature, the North Atlantic Oscillation (NAO) and the Madden-Julian Oscillation (MJO) (Ginoux et al., 2004; Wong et al., 2008; Guo et al., 2013). In addition, the African dust in the Sahara air layer region influences the rates of rainfall in the Intertropical Convergence Zone (ITCZ) (Huang et al., 2009, 2010), and its radiative impacts can shift and widen the ITCZ northward (Bangalath and Stenchikov, 2015).

African dust is transported in great quantities to the Caribbean basin throughout the year, although the strong seasonal cycle shows the maximum transport of dust in the boreal summer and the minimum in winter (Prospero et al., 2014; Yu et al., 2015). The seasonality is corroborated by satellite measurements of aerosol optical depth (AOD), which show extensive plumes of high AOD in summer extending from the western coast of Africa to the Caribbean, the Gulf of Mexico, and the southern United States (Hsu et al., 2012; Yu et al., 2013; Chin et al., 2014; Kim et al., 2014; Groß et al., 2015). The satellite data also indicate that the dust transport to the western Atlantic in winter and spring is comparable, but the dust is largely confined to the southern latitudes of Barbados with a plume axis crossing the coast of South America in the region of French Guiana and Suriname. In addition, satellite data indicate a decrease of $50 \%$ in AOD and a decrease of $0.1-0.2$ in the dust-only optical depth during the transport (Kim et al., 2014). The ITCZ acts as an efficient removal mechanism (Prospero et al., 2014) and thus as a barrier to the transport of dust to the southern Atlantic (Huang et al., 2009, 2010; Adams et al., 2012). To characterize the transatlantic dust transport, many studies have used satellite observations (Liu et al., 2008; Ben-Ami et al., 2009; Ben-Ami et al., 2012; Ben-Ami et al., 2010; Adams et al., 2012; Ridley et al., 2013;
Alizadeh-Choobari et al., 2014; Kim et al., 2014; Yu et al., 2015). However, the estimation of the satellitebased dust flux has large uncertainties, primarily because of ambiguity associated with the derived dust-only optical depth (Yu et al., 2009, 2013) and the dust mass extinction efficiency. Both parameters are used to calculate the dust mass loading (Kaufman, 2005).

One cause of uncertainty is the chemical aging of mineral dust. For instance, the condensation of inorganic acids, such as nitric acid $\left(\mathrm{HNO}_{3}\right)$, can alter the particle size due to changes in the hygroscopicity of the dust particles (Metzger et al., 2006; Karydis et al., 2016). $\mathrm{HNO}_{3}$, which is an oxidation end product of combustion processes and lightning $\mathrm{NO}_{x}$ and therefore ubiquitous in the atmosphere, readily reacts with the calcium of the mineral dust surface. The neutralization product, calcium nitrate, additionally takes up ambient water vapor, which can change the particle (wet) radius. This process of water uptake can become significant, since it already starts at a relative humidity as low as $50 \%$ (the relative humidity of deliquescence (RHD) of $\mathrm{Ca}\left(\mathrm{NO}_{3}\right)_{2}$ is $48 \%$ at $T=298 \mathrm{~K}$ ). In strong contrast, dust coating by sulfuric acid $\left(\mathrm{H}_{2} \mathrm{SO}_{4}\right)$ does not lead to such hygroscopic particles, since the RHD of $\mathrm{CaSO}_{4}$ is close to $100 \%$ (at any $T$ ). Thus, the coating by nitrates can determine the hygroscopicity of mineral dust particles in the case of a polluted atmosphere (Bauer et al., 2007; Sullivan et al., 2007; Li and Shao, 2009; Tobo et al., 2009, 2010; Li et al., 2013). The growth of the particles increases the scattering cross sections and therefore alters the AOD; it indirectly affects the cloud scavenging efficiency (Lance et al., 2013; Wu et al., 2013; Li et al., 2013), potentially increasing the wet and dry removal of the dust particles (Abdelkader et al., 2015).

Therefore, the dust cycle and the associated impacts are found to be challenging for global and regional modeling because the complex dust processes have to be parameterized using a suite of simplifications (Astitha et al., 2010; Nowottnick et al., 2010; Huneeus et al., 2011; Ridley et al., 2013; Kim et al., 2014; Gläser et al., 2015). Although most sophisticated atmospheric models can reproduce the transatlantic dust transport plumes, the patterns differ in magnitude and seasonality. Generally, the models show better performance in summer than in winter for the transatlantic dust transport (Huneeus et al., 2011). It has been observed that large uncertainties exist between the model simulations of the dust deposition (wet and dry) (Schulz et al., 2012). The atmospheric models that are applied in the AeroCom intercomparison (http://aerocom.met.no/) show that the mean normalized bias of the AOD varies within a wide range from -0.44 to 0.27 (Huneeus et al., 2011), which is caused by large discrepancies in the dust-related processes (emission, horizontal and vertical distributions and the parameterization of chemical aging) that affect the dust transport from northern Africa over the Atlantic Ocean (Prospero et al., 2010). This indicates that in these models the dust removal is very efficient during the transatlantic transport (Kim et al., 2014) and that the develop- 
Table 1. The EMAC submodels used in the current study and the corresponding references.

\begin{tabular}{lll}
\hline Submodel & Description & Reference \\
\hline AEROPT & Aerosol optical properties & Lauer et al. (2007); Klingmüller et al. (2014); Pozzer et al. (2015) \\
CLOUD & ECHAM5 cloud scheme as MESSy submodel & Roeckner et al. (2006) \\
CONVECT & Convection parameterizations & Tost et al. (2010) \\
CVTRANS & Convective tracer transport & Tost et al. (2006b) \\
DDEP & Dry deposition & Kerkweg et al. (2006a) \\
EQSAM4clim & Fast aerosol thermodynamics & Metzger et al. (2016) \\
GMXe & Aerosol dynamics and microphysics & Pringle et al. (2010) \\
ISORROPIA-II & Aerosol thermodynamics & Fountoukis and Nenes (2007) \\
JVAL & Online photolysis rates & Landgraf and Crutzen (1998) \\
LNOX & NOx production from lightning & Tost et al. (2007) \\
MECCA & Gas phase chemistry & Sander et al. (2005) \\
OFFEMIS & Prescribed emissions of trace gases and aerosols & Kerkweg et al. (2006a) \\
ONEMIS & Online calculated emissions & Kerkweg et al. (2006b); Astitha et al. (2012) \\
RAD & ECHAM5 radiation scheme as MESSy submodel & Roeckner et al. (2006); Jöckel et al. (2010) \\
SCAV & Comprehensive scavenging of aerosols and gases & Tost et al. (2006a) \\
SEDI & Sedimentation of aerosols & Kerkweg et al. (2006a) \\
TNUDGE & Newtonian relaxation of species & Kerkweg et al. (2006a) \\
TROPOP & Tropopause and other diagnostics & Joeckel et al. (2006) \\
\hline
\end{tabular}

ment of the model requires a comprehensive representation of the dust-related processes. Though the incorporation of satellite products helps improve the model results, a deeper understanding of the key factors that determine the transport of the dust is also required. This study aims to examine the factors that can affect the transatlantic dust transport, i.e., the emission flux, convection schemes and the chemical aging of mineral dust, by using the EMAC model.

\section{Model description}

We use EMAC (ECHAM5/MESSy2 Earth System Model) following Abdelkader et al. (2015). The EMAC model describes the tropospheric and middle atmosphere processes and their interactions with land and oceans by considering various submodels (Jöckel et al., 2010); those used in this study are listed in Table 1 . The mineral dust particles are emitted in two lognormal distribution modes (accumulation and coarse) with median diameters of 0.5 and $5.0 \mu \mathrm{m}$ and modal standard deviations of 1.59 and 2.0 for the accumulation and coarse modes, respectively (Abdelkader et al., 2015). The anthropogenic emissions are based on the EDGARv4.0 inventory (Pozzer et al., 2012) and include greenhouse gases, $\mathrm{NO}_{x}, \mathrm{CO}$, non-methane volatile organic compounds (NMVOCs), $\mathrm{NH}_{3}, \mathrm{SO}_{2}$, black carbon (BC) and organic carbon (OC) from fossil fuel and biofuel use. The monthly large-scale biomass burning emissions of OC, BC and $\mathrm{SO}_{2}$ are based on GFED version 3 (Global Fire Emissions Database) (van der Werf et al., 2010). The emissions drive a comprehensive atmospheric chemistry mechanism (Sander et al., 2005), which calculates major inorganic acids $\left(\mathrm{H}_{2} \mathrm{SO}_{4}, \mathrm{HNO}_{3}\right.$ and $\left.\mathrm{HCl}\right)$ online with meteorology. Organic acids are not considered in this model setup since their concentrations over the Sahara during dust outflow are very low, though many modeling studies have reported the uptake of organic acids by dust particles (Metzger et al., 2006; Möhler et al., 2008; Liu et al., 2013; Li et al., 2013; Alexander et al., 2015; Wang et al., 2015).

The chemical aging of the dust depends on the condensation of inorganic acids and the associated uptake of water vapor. This increases the dust particle mass, particle size and the removal rates, which tends to decrease the lifetime of chemically aged dust. The condensation of acids in our model yields the anions sulfate $\left(\mathrm{SO}_{4}^{2-}\right)$, bisulfate $\left(\mathrm{HSO}_{4}^{-}\right)$, nitrate $\left(\mathrm{NO}_{3}^{-}\right)$and chloride $\left(\mathrm{Cl}^{-}\right)$, whereas the condensation of ammonia $\left(\mathrm{NH}_{3}\right)$ yields a semivolatile cation, ammonium $\left(\mathrm{NH}_{4}^{+}\right)$, that reacts with the inorganic anions in competition with the mineral cations $\mathrm{Na}^{+}, \mathrm{Ca}^{2+}, \mathrm{K}^{+}$and $\mathrm{Mg}^{2+}$ (Metzger et al., 2006). However, in this study, the cations are considered reactivity proxies for natural aerosols, such as sea salt, biomass burning or mineral dust; we follow Abdelkader et al. (2015) and use a fixed percentage. These fractions have been derived from a comprehensive sensitivity study (which will be presented in a separate paper) to achieve the best agreement of the cation and anion concentrations with various station observations from 2000 to 2012 (see Sect. 3). The anion-cation neutralization products (salt compounds), simulated by the aerosol thermodynamic models ISORROPIA II (Fountoukis and Nenes, 2007) or EQSAM4clim (Metzger et al., 2016), can alter the hygroscopicity of the atmospheric dust particles; however, the effect strongly depends on the atmospheric residence time, region and concentrations of acids. Generally, dust chemical aging changes the solubility, which controls the water uptake and in turn al- 


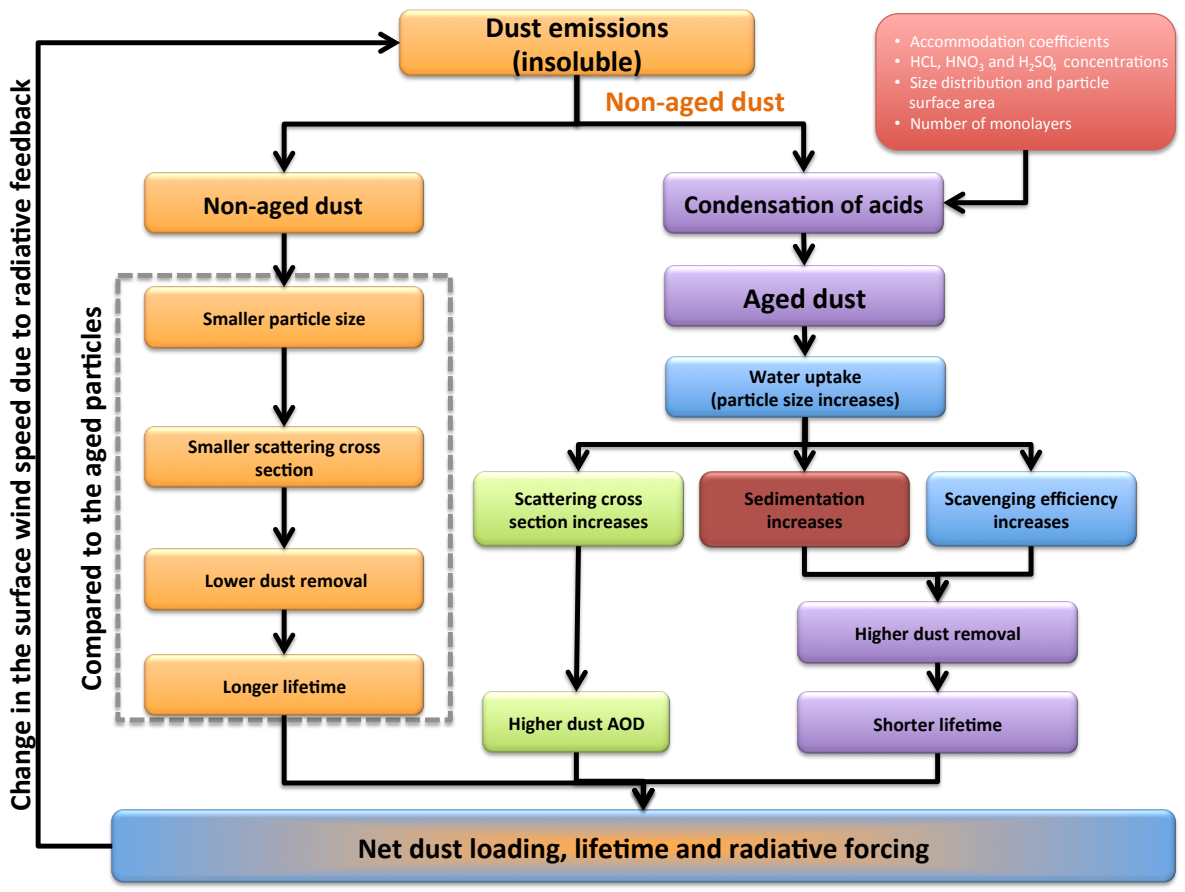

Figure 1. A schematic representation of the dust cycle and the feedback from air pollution, dust, chemical aging and radiation in EMAC. Air pollution controls the chemical aging of dust particles, whereby the consequent water uptake increases the dust particle scattering cross section and enhances the dust deposition (wet and dry), which tends to decrease the dust lifetime. The net radiative differences between aged and non-aged dust particles are indicated.

ters the aerosol size distribution (Metzger et al., 2006). The water uptake is a key parameter and important for aerosolradiation feedback, aerosol in-cloud processing (nucleation scavenging) and below-cloud (impaction) scavenging. The EMAC scavenging processes include detailed $\mathrm{pH}$-dependent aqueous phase chemistry (Tost et al., 2006a), which is fully coupled with the aerosol and gas phase chemistry, liquid cloud water and ice crystals. In addition to the aerosol hygroscopic growth and scavenging, the dust size distribution can change through coagulation, and smaller particles can grow into larger sizes for both the soluble and insoluble aerosol modes (Pringle et al., 2010); aerosol hygroscopic growth is only allowed in the soluble modes (Abdelkader et al., 2015). Dry deposition and particle sedimentation can remove all particles from the atmosphere depending on the particle size (Kerkweg et al., 2006a). Thus, the representation of the dust cycle in our EMAC setup couples the dust emissions, loading and lifetime with the radiative forcing and model dynamics. As a result, changes in the dust loading feed back into the surface wind speed, soil moisture, cloud formation and precipitation, and in turn the dust emission flux. Overall, the level of air pollution controls the dust cycle because it determines the level of dust chemical aging by inorganic acids and water vapor. A Newtonian relaxation approach is used to nudge the model meteorology in the free atmosphere (i.e., above the boundary layer) to achieve a realistic simulation of the surface wind speed and tracer transport (Abdelkader et al.,
2015). Nudging significantly improves the surface dust mass concentration over the Caribbean compared with the dust observations (Astitha et al., 2012). The model spectral resolution is T106 $(\approx 110 \mathrm{~km})$; for the long-term simulations it is $\mathrm{T} 42(\approx 280 \mathrm{~km})$. Both model resolutions use 31 vertical levels. Figure 1 summarizes the representation of the dust cycle and the feedback from air pollution, dust, chemical aging and radiation in our EMAC model setup.

\section{Long-term evaluation}

This study aims to examine the key factors that affected the transatlantic dust transport for a major dust outflow event in July 2009 with a model resolution of T106, which is presented in Sect. 4. Before we focus on the sensitivity study, in this section we present the key findings of a comprehensive model evaluation, which was performed for 2000-2012 with a coarser resolution of T42. For the long-term evaluation, we use the following satellite and ground station AOD products:

- AErosol RObotic NETwork (AERONET); Holben et al. (1998);

- Cloud-Aerosol Lidar and Infrared Pathfinder Satellite Observations (CALIPSO); Winker et al. (2009, 2007);

- MODerate Resolution Imaging Spectroradiometer (MODIS) platforms Aqua and Terra 


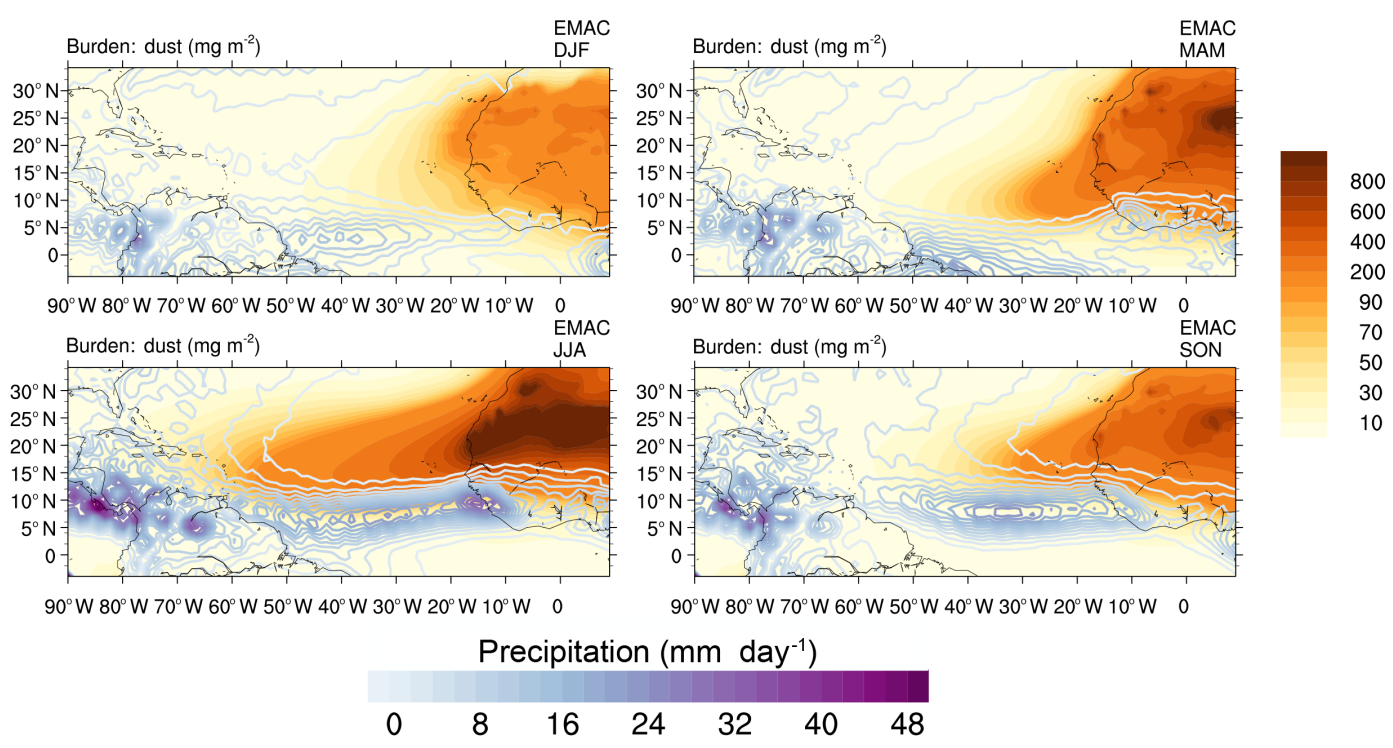

Figure 2. Seasonal averages of the dust burden and precipitation representing the transatlantic dust outflow for the entire model evaluation period (2000-2012). The dust burden and precipitation are at a maximum during the boreal summer and at a minimum during winter. The orange coloring represents the dust burden, while the purple coloring (contour lines) depicts precipitation.

(product collection 6, L3 gridded data); Kaufman et al. (1997);

- Precipitation data from the Tropical Rainfall Measuring Mission (TRMM)

(product version 31, L3 gridded data); Diner et al. (1998);

Figure 2 shows the seasonal average of the simulated dust burden and the precipitation rate over a 13-year simulation period. Both the dust burden and the precipitation rate peak during the summer season (JJA), where the dust plume is located relatively far north of the Equator, are in agreement with remote-sensing observations (Prospero et al., 2014; Yu et al., 2015). During the winter season (DJF), the dust burden and the precipitation rate show a minimum, whereas during the spring season (MAM), the dust plume and the ITCZ are shifted southward. In winter and spring, the dust transport shifts southward to $0-10^{\circ} \mathrm{N}$ and affects South America significantly, whereas during summer, the dust transport occurs predominantly at $10-20^{\circ} \mathrm{N}$, substantially affecting the Caribbean (Yu et al., 2015). During the boreal winter, the enhanced precipitation over the northern part of South America results in higher and more localized dust scavenging because the precipitation along the dust transport from western Africa into the Caribbean is at a minimum. In contrast, during the boreal summer, the dust spreads to a larger extent into the ITCZ because of the stronger emissions (Prospero et al., 2014) while it is subject to enhanced dust scavenging. The strong southward gradient of the dust burden $\left(\approx 100 \mathrm{mg} \mathrm{m}^{-2} \mathrm{deg}^{-1}\right)$ is collocated with precipitation in the western part of the Sahel and the ITCZ region. During the winter months, dust is primarily scavenged over the south- eastern part of South America. As a result, the extent of the dust outflow is primarily controlled by precipitation in the ITCZ region. Figure S1 in the Supplement shows the dry and wet removal of the dust particles. It shows that the dry removal dominates the northern part of the dust outflow region, whereas the wet removal dominates the southern part.

To indicate the region where the dust interacts with the ITCZ, we introduce the dust-ITCZ (DIZ) zone, which is shown in Fig. 3. The DIZ is marked by a blue line, and the AERONET station locations used to evaluate the simulated AOD are included. In the DIZ region, the transatlantic dust transport is controlled by dust-cloud interactions, and the dust scavenging is the most efficient. Accordingly, we refer to the region of the predominant dry removal process (sedimentation) as the DTA zone.

Summarizing the long-term evaluation results, Fig. 4 shows the following: (i) the transatlantic dust transport region with the skill score (Taylor, 2001) at each station (see Appendix A for the evaluation metrics); (ii) the time series of the six selected stations that provide long-term data with three stations each in the Caribbean (left) and around western Africa (right); and (iii) corresponding scatter plots of both sides of the Atlantic Ocean that include the observations from all stations. Table 2 summarizes the model performance for both regions over the entire period (2000-2012) for all stations. The 13-year average (based on output every $5 \mathrm{~h}$ ) of the simulated AOD for the western African sites is $0.16 \pm 0.27$ ( 1 standard deviation), which is lower than the observation of $0.24 \pm 0.37$. The difference is larger compared to that for the Caribbean, for which the average simulated $\mathrm{AOD}$ is $0.12 \pm 0.18$ and $0.14 \pm 0.22$ according to the obser- 


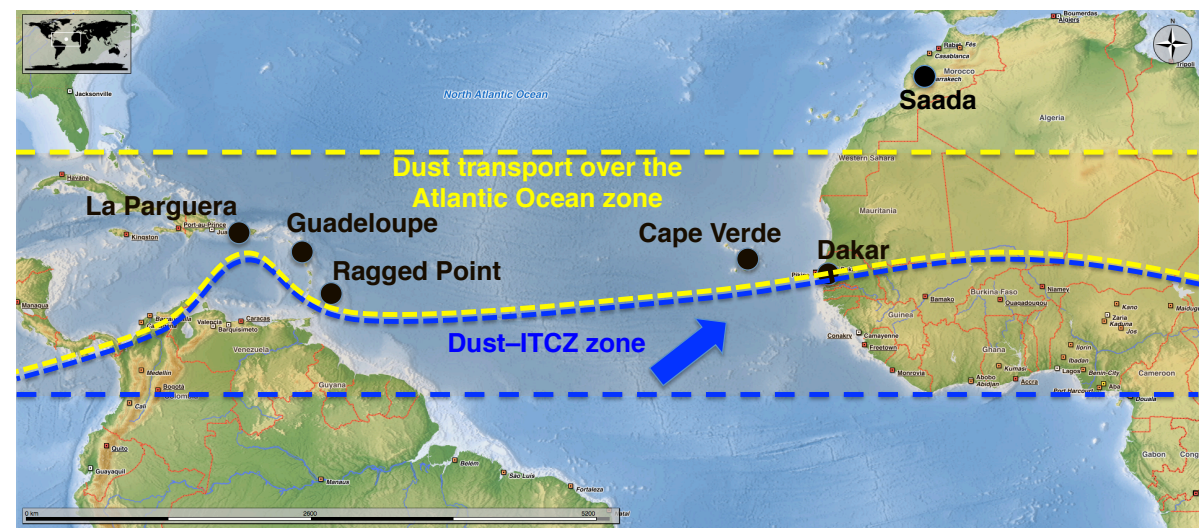

Figure 3. The locations of selected AERONET stations used in the transatlantic dust transport study. These include Saada, Cape Verde, and Dakar as western African stations and La Parguera, Guadeloupe, and Ragged Point as Caribbean stations. The upper blue line shows the approximate northern boundary of the ITCZ, and the yellow box indicates the adjacent dust transport region (DTA). The region within the blue boundaries represents the dust-ITCZ interaction zone (DIZ). These regions are defined according to the predominance of the dust removal mechanism shown in Fig. S1 in the Supplement.
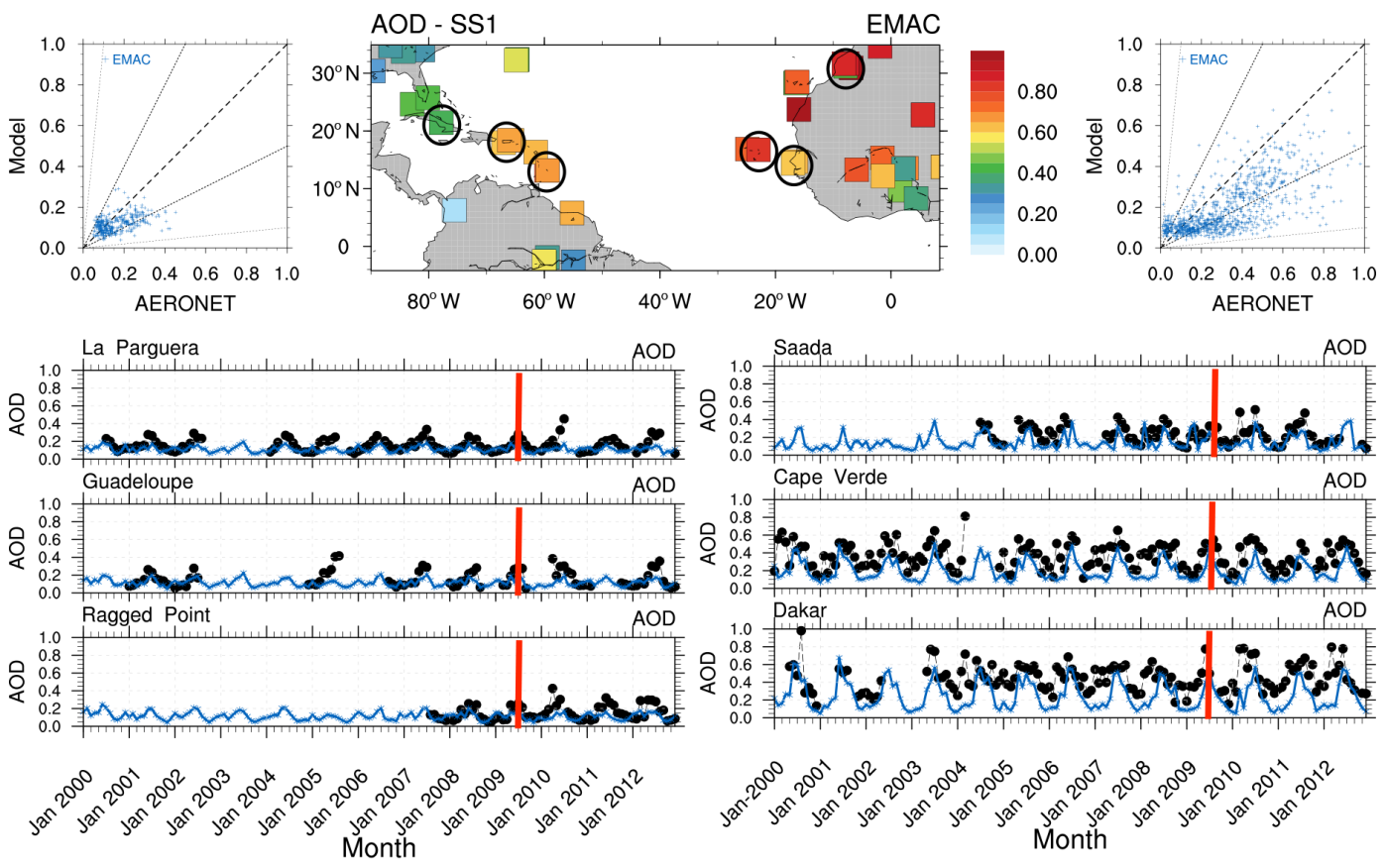

Caribbean

West Africa

\section{AERONET *EMAC}

Figure 4. The long-term evaluation of AOD (2000-2012) over western Africa and the Caribbean. The top panel represents scatter plots including all observations from all stations (left for the Caribbean, right for the western African region) and the skill score (SS1) as defined in Appendix A. The lower panel depicts a time series for stations in both regions (monthly means of $5 \mathrm{~h}$ averages for the model and AERONET AOD). The red bars represent the July 2009 dust outflow period, and the black circles depict the selected AERONET stations shown in Fig. 3 within observations for the period of our sensitivity simulations. The dotted lines in the scatter plot show the $1: 2$ and $1: 10$ ratios.

vations. On both sides of the Atlantic, the lower variability of the model is primarily a result of the relatively coarse model resolution (T42 $\approx 280 \mathrm{~km}$ ) (Gläser et al., 2012), which was used for these long-term simulations because of a signifi- cantly larger computational burden for the higher T106 resolution. The skill score (SS1) values are 0.73 and 0.70 for the western African and Caribbean stations, respectively. 
Additionally, the correlation coefficients ( $R$; Table 2$)$ are lower than the SS1, because $R$ is more phase sensitive than the SS1 (i.e., more sensitive to time lags between the simulated and the observed AOD). The higher $R$ value for western Africa (0.61) compared with the Caribbean (0.41) mainly results from the higher overall contribution of dust AOD to the total AOD. Typically, the Caribbean is strongly influenced by the uncertainty associated with long-range transport and dust chemical aging, with potential failures causing a time shift of dust peaks during the transport. These differences are, however, best revealed by station time series (Fig. 4). The six stations are selected based on the availability of observations from 2000 to 2013, while the other stations have a significantly lower number of observations and therefore lower skill scores. The comparison shows that the model captures the variability of the AOD at all stations, and only around western Africa does the model underestimate the AOD peaks; this is especially true at Dakar, which is at the edge of the DIZ zone. Over the Caribbean, the model generally underestimates the AOD during the dust outflow periods, e.g., seen at the AERONET station at La Parguera. This underestimation could be related to the representation of dust emissions and related processes in the source region of western Africa (Huneeus et al., 2011; Shao et al., 2011; Cuevas et al., 2015) by overestimated removal during transport (Schulz et al., 2012; Prospero et al., 2014) or due to low-biased dust transport from the boundary layer into the free atmosphere (Khan et al., 2015). The underestimation of the AOD could also be due to the missing fraction of giant mode particles (larger than $10 \mu \mathrm{m}$ ), which may contribute to an underestimation of the AOD near the dust source region. However, giant particles are not transported far over long distances and hence are not really relevant for the long-range transport or our sensitivity study on the emission flux and removal mechanisms.

\section{Sensitivity studies}

To study the key factors that may affect the transatlantic dust transport, we focus in this section on a major dust outflow event that occurred in July 2009. We study the impact of various key factors with a relatively high model resolution (T106). In terms of AOD, the dust outflow is close to most observations, as indicated by the monthly means highlighted by the red bar in Fig. 4. However, near the source region at Dakar and Cape Verde, the AOD observations are underestimated for this month. During this period, a major outflow event occurred, and therefore it seems suitable to test various model parameters: (a) the dust emission flux, (b) the convection parameterization and (c) the level of dust chemical aging.

Figure 5 shows the dust burden and the total mean precipitation for July 2009 from the reference EMAC simulation, which includes the dust cycle and chemical aging as shown in
Table 2. The long-term EMAC model evaluation for the AOD from 2000 to 2012. Statistics are given for both sides of the Atlantic based on the selected AERONET sites around western Africa and the Caribbean (station average). The evaluation metrics are defined in Appendix A, while the station locations are shown in Fig. 3.

\begin{tabular}{lrr}
\hline & Western Africa & Caribbean \\
\hline Mean $_{\mathrm{m}}$ & $0.16 \pm 0.27$ & $0.12 \pm 0.18$ \\
Mean $_{\mathrm{O}}$ & $0.24 \pm 0.37$ & $0.14 \pm 0.22$ \\
$r_{\mathrm{m}}$ & $0.13 \pm 0.40$ & $0.11 \pm 0.27$ \\
$r_{\mathrm{O}}$ & $0.29 \pm 0.35$ & $0.13 \pm 0.29$ \\
$\mathrm{RMSE}$ & 0.35 & 0.23 \\
$R$ & 0.61 & 0.43 \\
MBE & -0.19 & -0.11 \\
$\mathrm{GFE}$ & -0.24 & -0.12 \\
$\mathrm{SS} 1$ & 0.73 & 0.70 \\
PF2 & 0.59 & 0.81 \\
PF10 & 1.00 & 1.00 \\
NPOINTS & 50288 & 15827 \\
\hline
\end{tabular}

Fig. 1. The simulated dust surface concentration reaches on average up to $600 \mathrm{\mu g} \mathrm{m}^{-3}$ at Dakar, indicating that the model captures the strong outflow event. Generally, two strong precipitation areas are visible with one peak centered at $15^{\circ} \mathrm{W}$ with a monthly average of $20 \mathrm{~mm} \mathrm{day}^{-1}$; one peak area is at the coast of western Africa, and the other peak area is located in the Caribbean at $50^{\circ} \mathrm{W}$ with a monthly average of $25 \mathrm{~mm}$ day $^{-1}$. These precipitation maxima influence the dust loading. During transatlantic dust transport, the ITCZ represents a strong barrier for the dust outflow and therefore controls the meridional extent of the dust plume (Yu et al., 2015). The ITCZ acts as a major sink that depends on the amount of precipitation (Prospero et al., 2014; Schlosser et al., 2014), and the removal might be enhanced depending on the dust chemical aging (Abdelkader et al., 2015). Clearly, the precipitation within the ITCZ coincides with the steep gradient of the dust burden in the meridional direction over western Africa. Along the zonal extent of the dust plume, the collocation of the dust plume and precipitation corroborates the theory that the meridional extent of the dust is primarily controlled by the location of the ITCZ. Figure S1 in the Supplement summarizes the monthly average dust removal in July 2009. Table S1a and Table S1b in the Supplement additionally show some evaluation metrics for the AOD of the sensitivity study over the western African and Caribbean stations.

Typically, African dust outflow reaches the Caribbean $\approx 5$ days later (Gläser et al., 2015), and the surface dust concentration is significantly lower over the Caribbean compared to western Africa. Figure 6 shows the time series of the sizeresolved surface dust concentrations. Two main dust outflows on 2 and 12 July are simulated at the Cape Verde station, indicated by dust concentrations higher than or close to $300 \mu \mathrm{g} \mathrm{m}^{-3}$ (equivalent particle cutoff diameter of $5 \mu \mathrm{m}$ ). Another weaker dust outflow is simulated on 24 July, indi- 


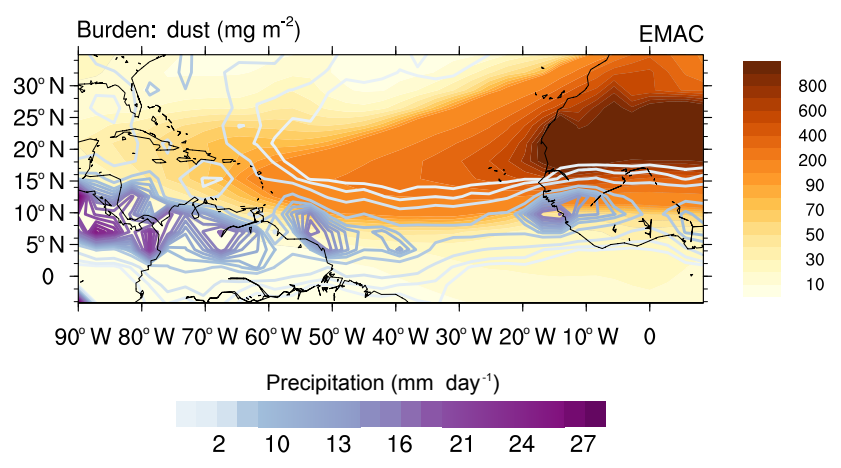

Figure 5. The EMAC computed spatial distribution of the dust burden (orange) and total precipitation (purple lines) for the reference simulation for July 2009 (monthly mean).

cated by a lower concentration peak around $100 \mu \mathrm{g} \mathrm{m}^{-3}$. The former two dust outflows are seen at Dakar with twice the concentration (up to $600 \mu \mathrm{g} \mathrm{m}^{-3}$ ) at slightly different time periods due to different transport. Eventually, the dust outflow reaches the Caribbean with a significantly lower concentration of around $60 \mu \mathrm{g} \mathrm{m}^{-3}$ at Earth's surface.

Despite chemical aging, the model simulates a majority of the dust particles in the insoluble coarse (ci) mode, which indicates that the dust particle concentration is high and/or the inorganic acid concentration is relatively seen as too low for complete chemical aging. This is especially valid for strong dust outflows, such as those studied here. On the other hand, the fraction of the aged dust, i.e., the ratio of the coarse mode soluble to insoluble particles (cs / ci), is somewhat higher in the Caribbean because of the continuous chemical aging during long-range transport. The aged dust fraction over western Africa is about $10 \%$ of the total dust mass and twice that at the Caribbean sites. The same is true for the dust in the accumulation modes (ai and as), but the mass concentrations are an order of magnitude lower compared to the coarse mode concentrations, and therefore they are not discernable at the linear scale. At higher elevations, this fraction can be different because of different dust and precursor gas concentrations.

To investigate the vertical distribution, the simulated dust extinction is compared with the dust subtype classification of the CALIPSO retrievals. Figure 7 shows a comparison for the second dust outbreak on 12 July 2009. The figure shows a subset of four collected CALIPSO tracks and includes a qualitative comparison of the dust layer height. The scatter plot attached to each panel represents the point-to-point comparison colored by the height of each observation point, whereas the area plots show the dust burden interpolated in time to the CALIPSO overpass time indicated by a solid black line. Additional CALIPSO tracks are shown in Fig. S2a-e in the Supplement. Both EMAC and CALIPSO show that dust over the Sahara reaches an elevation of up to $7 \mathrm{~km}$. The dust burden is very low (as indicated by the area plot) south of $10^{\circ} \mathrm{N}$, which coincides with a very low AOD observed by CALIPSO. Both EMAC and CALIPSO show that the dust plume is limited to the area between 14 and $22^{\circ} \mathrm{N}$, and the top of the dust layer is lowered to $5 \mathrm{~km}$ over the middle of the Atlantic. This is primarily a result of the prevailing deposition (gravitational settling plus wet removal), which is further discussed in the following sections. Once the dust reaches the Caribbean, the plume spreads over a considerably larger area, which extends from 5 to $28^{\circ} \mathrm{N}$ as a result of changes in meteorological conditions. The dust plume eventually reaches the Caribbean with a top layer height of $\approx 5 \mathrm{~km}$. In Fig. 7, the comparison with CALIPSO (and Fig. S2a-e in the Supplement) shows that the model captures the vertical structure of the dust outbreak during the transport over the Atlantic Ocean. Nevertheless, the model tends to systematically overestimate the dust extinction at lower altitudes, whereas at higher altitudes the model tends to underestimate the CALIPSO extinction (considering all CALIPSO tracks in Figs. 7 and S2a-e in the Supplement). This indicates that EMAC might remove the dust too efficiently during transport. The reasons can be manifold and related to different processes of the dust cycle (Fig. 1). Therefore, the key factors are investigated further in greater detail.

\subsection{Dust emission flux}

A successful representation of the dust cycle first depends on an accurate dust emission flux. However, the simulated emission flux critically depends on many model parameters, some of which are resolution dependent. Using EMAC, the dust emissions are calculated considering the friction velocity following Astitha et al. (2012). To test the sensitivity of the transatlantic dust transport to the dust emission parameterization, several sensitivity simulations were performed, which are summarized in Table 3 . The total dust mass emitted in July 2009 within the region between $20^{\circ} \mathrm{W}$ and $10^{\circ} \mathrm{E}$ and 15 and $30^{\circ} \mathrm{N}$ is $0.6133 \mathrm{~kg} \mathrm{~m}^{-2}$ for the reference case.

The first test case (B1E1) represents a redistribution of emission bins between the coarse and accumulation modes, so that dust particles are shifted from the coarse to the accumulation mode while conserving the total dust mass. In this case, a larger amount of dust in the accumulation mode is transported over extended distances compared with the reference case EMAC. EMAC considers the same total dust mass with a larger fraction in the coarse mode. Additional sensitivity runs, B1E2 to B1E7, change the total dust emission flux by increasing the emission flux according to different factors as shown in Table 3. The horizontal dust emission flux is described by Eq. (1) (Marticorena and Bergametti, 1995; Astitha et al., 2012):

$$
H=\frac{c \rho_{\mathrm{air}} u_{*}^{3}}{g}\left(1+\frac{u_{\mathrm{t}}^{*}}{u^{*}}\right)\left(1-\frac{u_{\mathrm{t}}^{* 2}}{u^{* 2}}\right), u^{*}>u_{\mathrm{t}}^{*} .
$$

With the tuning parameter $c=1$ representing the reference case EMAC following Darmenova et al. (2009) and 

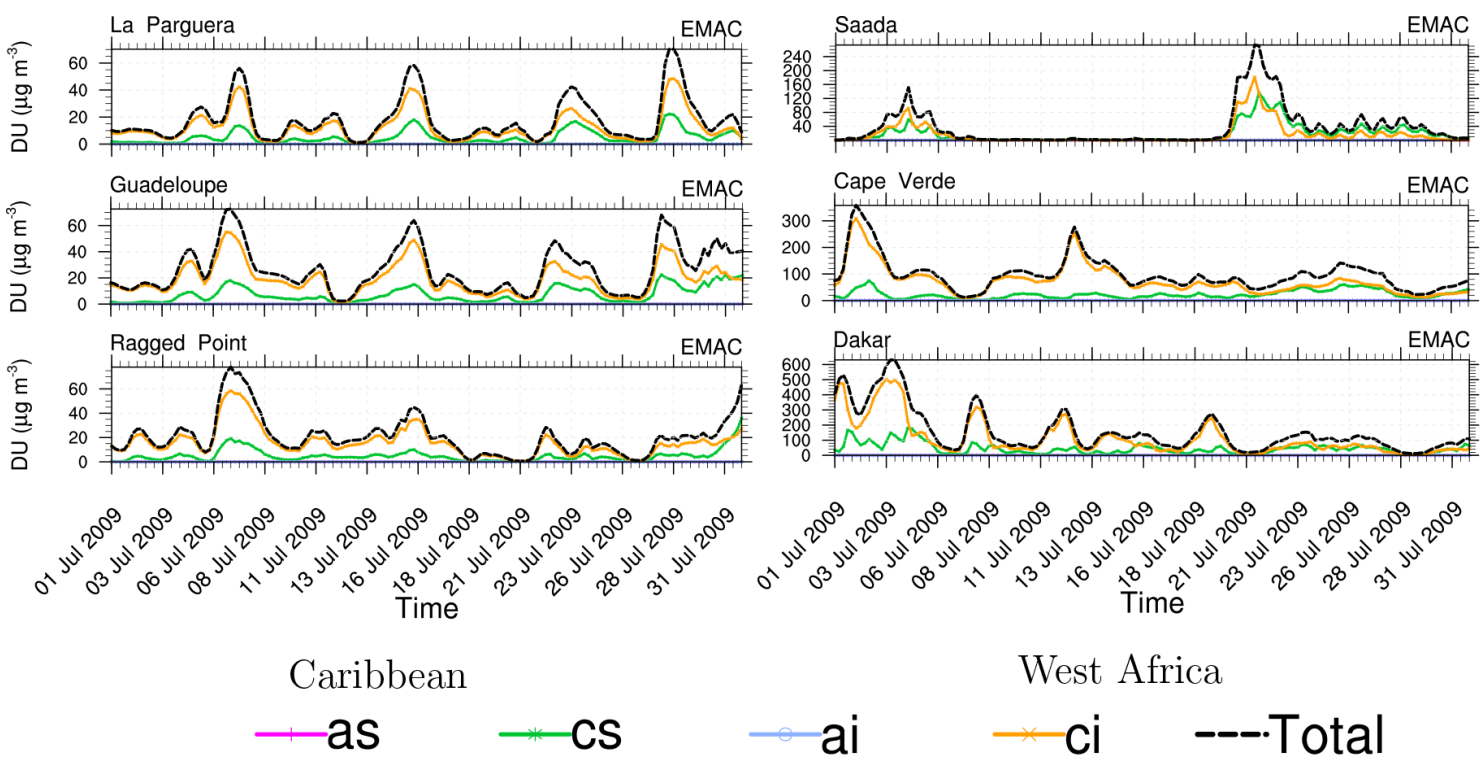

Figure 6. Time series of size-resolved surface dust concentrations for the different AERONET stations shown in Fig. 3. The aerosol modes are accumulation soluble (as), coarse soluble (cs), accumulation insoluble (ai) and coarse insoluble (ci). Note the different scaling, which reflects the wide range of concentrations at these stations. The accumulation mode dust fraction has a much lower contribution to the total dust concentration.

Table 3. A description of the transatlantic dust transport sensitivity simulations for two key processes: (i) emission flux (Sect. 4.1) and (ii) convection scheme (Sect. 4.2). The highlighted cases are shown in the paper (for all cases, see the Supplement, Figs. S3-S4). The emitted dust mass in July 2009 for the reference case is $0.6133 \mathrm{~kg} \mathrm{~m}^{-2}$.

\begin{tabular}{lll}
\hline Case & Description \\
\hline EMAC & Reference simulation \\
B1E1 & Redistribution of dust between accumulation and coarse modes \\
B1E2 & As EMAC, accumulation fraction incased by a factor of 2.61 \\
B1E3 & As EMAC, the coarse mode increased by a factor of 5.3 \\
Emission & B1E4 & As EMAC, the accumulation mode increased by a factor of 5.3 \\
& B1E5 & As EMAC, the accumulation mode increased by a factor of 10.6 \\
B1E6 & As EMAC, the accumulation and coarse modes increased by \\
& B1E7 & As EMAC, the accumulation and the coarse modes increased by a factor of 2.61 \\
B1E8 & As EMAC, factor = 2.61 in the horizontal flux \\
\hline EMAC & Reference simulation; TIEDTKE convection with NORDENG closure \\
B1T2 & TIEDTKE convection with TIEDTKE closure (Tiedtke, 1989) \\
B1T3 & TIEDTKE convection with HYBRID closure (Tiedtke, 1989) \\
B1T4 & ECMWF operational convection scheme (Bechtold et al., 2004) \\
& with the shallow convection closure of Grant and Brown (1999) \\
B1T5 & ECMWF operational convection scheme (Bechtold et al., 2004) \\
B1T6 & Zhang-Hack-McFarlane convection scheme (Zhang and McFarlane, 1995; Hack, 1994)
\end{tabular}

Astitha et al. (2012), $g$ is the gravitational acceleration, $\rho_{\text {air }}$ is the air density, $u^{*}$ is the friction velocity and $u_{\mathrm{t}}^{*}$ is the threshold friction velocity. For case B1E8, the horizontal mass flux is increased by a factor of 2.6 (parameter $c$ in Eq. 1). The cases highlighted in Table 3 are shown in Fig. 8, whereas the other cases are shown in the Supplement (Fig. S3).
Due to the different dry and wet deposition characteristics of the accumulation and coarse mode particles, significant differences are expected. Figure 8 shows that the AOD time series at the selected AERONET stations are rather insensitive to the emission flux modifications, except for case B1E3 (and B1E4, which is shown in the Supplement). This is valid for both sides of the Atlantic, where the AOD at the 

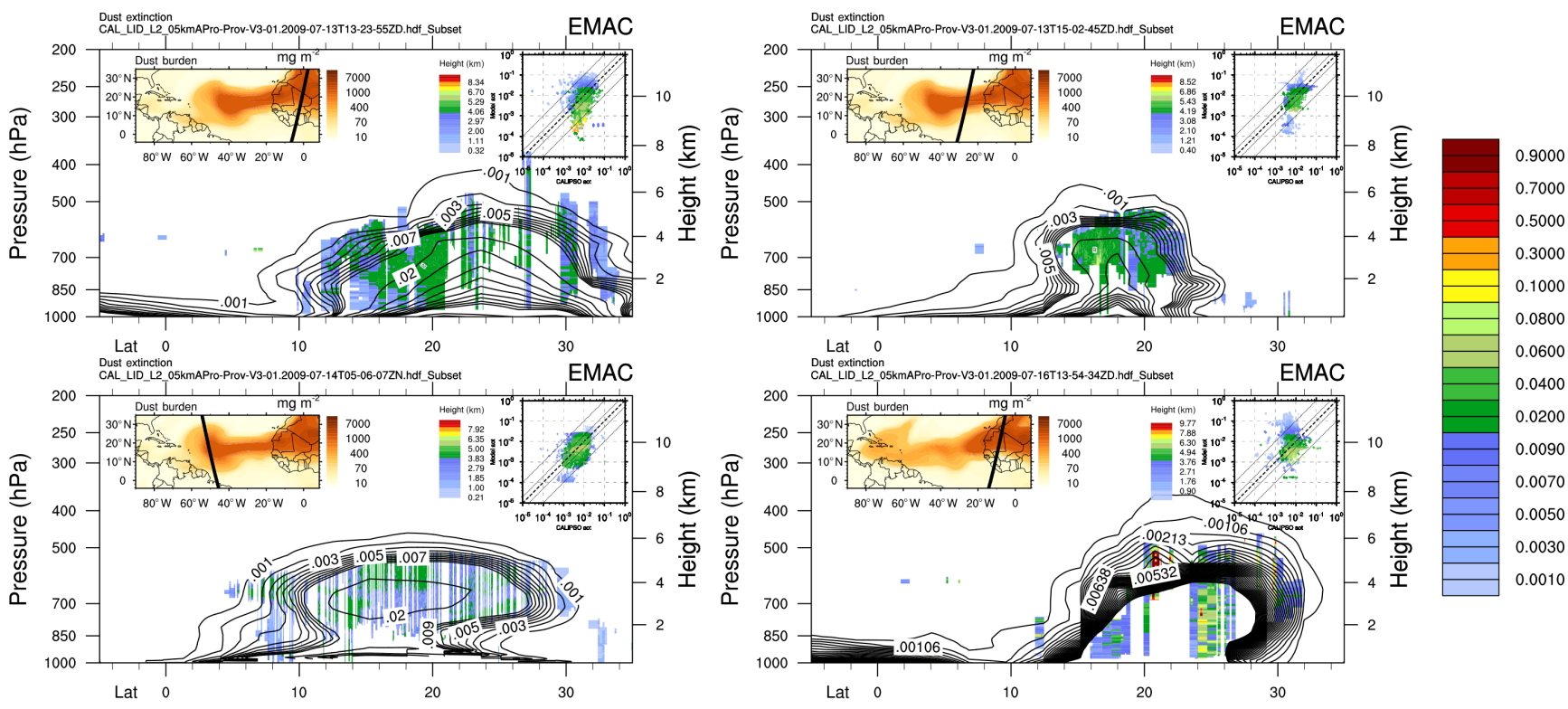

Figure 7. Collocated EMAC and CALIPSO observations of the dust extinction and burden for four different CALIPSO overpasses during the second dust outbreak over the Atlantic Ocean. The time of the overpass is shown in the upper left corners (13-16 July 2009). The solid lines show the simulated extinction, and the colored contours show the observed CALIPSO extinction, which is complemented by the scatter plots for a point-to-point comparison colored by the corresponding elevations of each observation (distinguished by the colors). The lines in the scatter plots delineate the 1-to-1, factor-2 and factor-10 intervals. All available comparisons with CALIPSO overpasses for this period are shown in the Supplement (Fig. S2a-e).

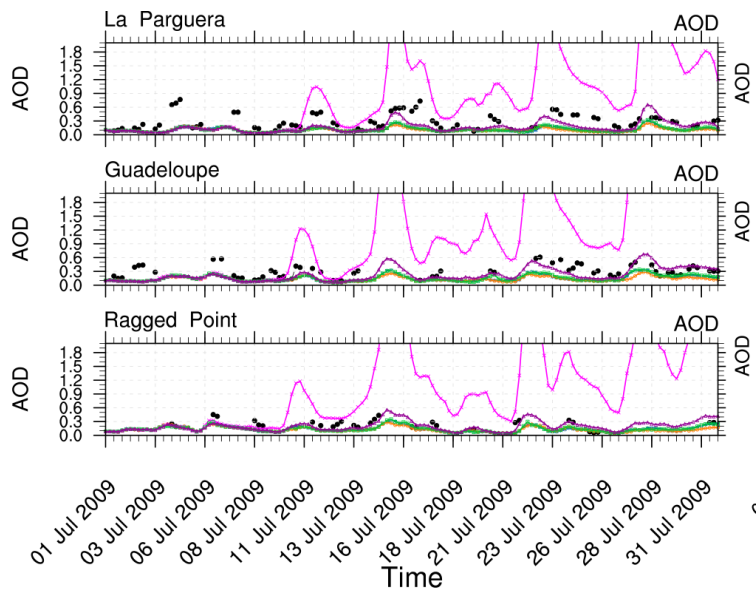

Caribbean

- AERONET $*$ EMAC B1E1 $\times$ B1E3
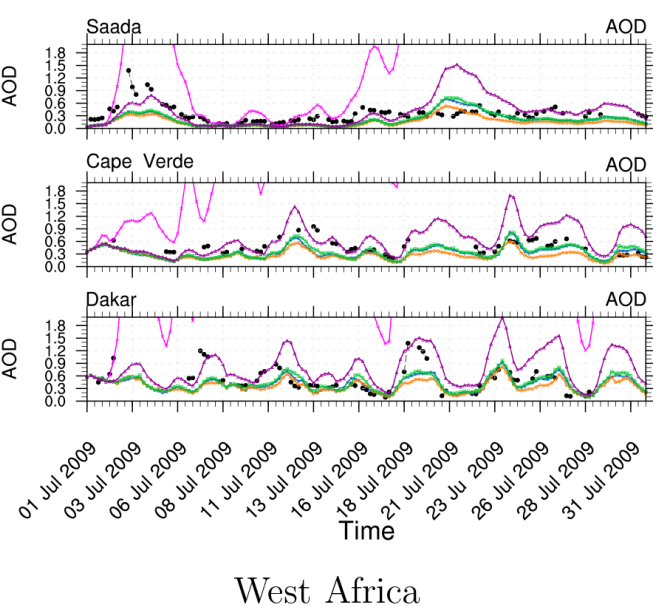

West Africa

Figure 8. EMAC and AERONET AOD for the western African (right) and Caribbean (left) sites based on different dust emissions (Table 3).

Caribbean stations seems even less sensitive than the AOD for the western African sites. Only for the cases in which the coarse mass flux is significantly increased (factor of 5.3) does the AOD show a higher sensitivity. The large increase in the coarse mode mass for case B1E3 results in a significant increase in AOD (exceeding 2.0) on both sides of the Atlantic Ocean. Case B1E8 (modification of the horizontal mass flux) shows better agreement with the AERONET observations on both sides of the Atlantic Ocean, despite the very high AOD values obtained on 21 July at the Saada station. The model captures the AOD during the two dust outflow events ( 2 and 12 July) at Cape Verde as well as the first dust outflow at Saada on 4 July. For the Caribbean sites, case B1E8 shows the best agreement with AERONET for the three stations.

The sensitivity simulations show that the accumulation mode fraction of the dust contributes much less to the AOD 

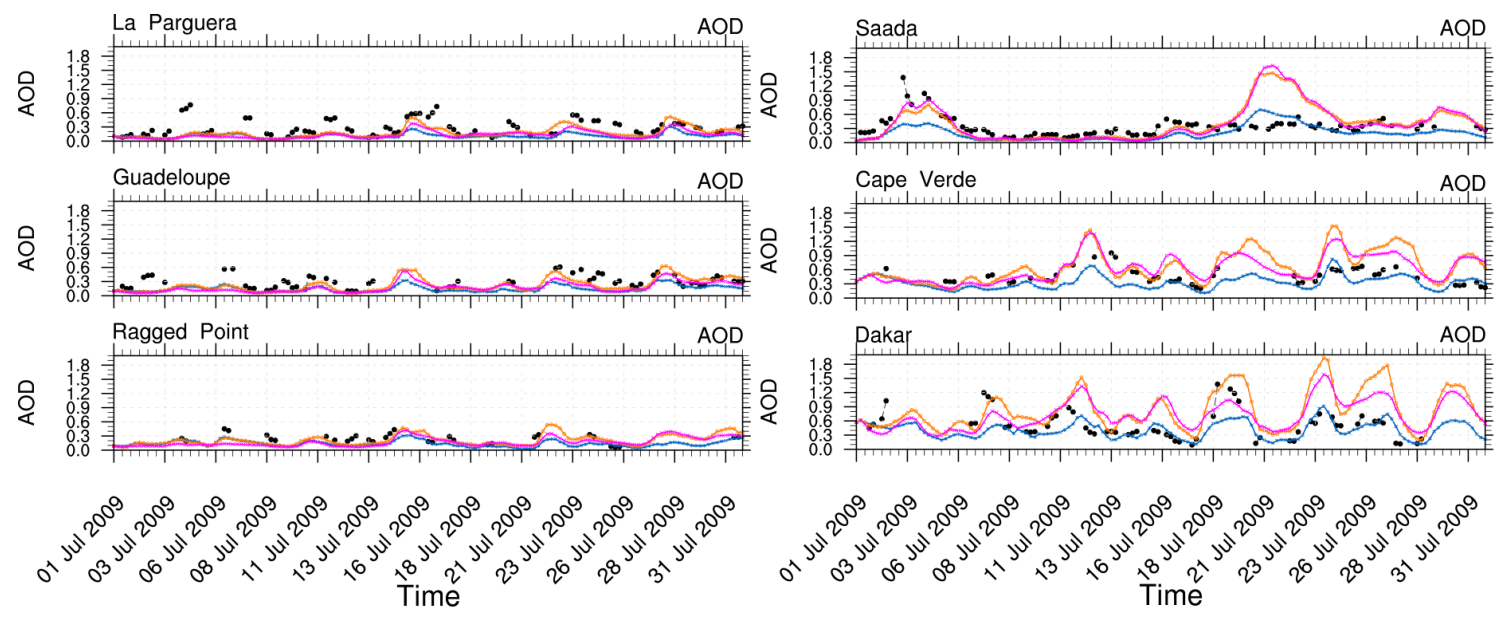

Caribbean
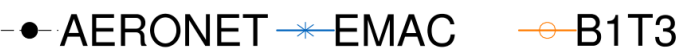

West Africa

Figure 9. EMAC and AERONET AOD for western Africa (right) and the Caribbean (left) based on different convection schemes (Table 3).

on both sides of the Atlantic Ocean because even an increase by a factor of 5.3 in the dust emission flux is not sufficient to match the observations. Instead, such an increase (by a factor of 5.3) in the emitted dust mass flux results in an unreasonable dust budget regionally and globally, as shown by Astitha et al. (2012). On the other hand, this sensitivity study shows that the AOD is more sensitive to the dust mass in the coarse mode and that the AOD over the Caribbean is much less sensitive to the total dust emission flux. Clearly, the model sensitivity is higher for the western African sites because these AOD results are more directly controlled by the Saharan dust outbreaks. To match the elevation at which this outflow occurs is equally important. The comparison with the CALIPSO observations (Fig. 7) reveals that EMAC overestimates the dust extinction at lower elevations, whereas the values at higher elevations are underestimated. This finding points to the strong contribution of dust removal during transatlantic dust transport and is largely controlled by the convection scheme.

\subsection{Convection schemes}

The scavenging of dust particles by precipitation is another key factor that controls the transatlantic dust transport (Kim et al., 2014). In order to study the impact of the convection and the associated precipitation during the dust outflow, different convection schemes implemented in EMAC by Tost et al. (2006b) are compared. The default scheme (TIEDTKE convection with NORDENG closure) provides realistic water vapor distributions on the global scale, which is crucial for radiative transfer processes and atmospheric chemistry (Tost et al., 2006b, 2010; Rybka and Tost, 2013). However, the radiative effect of aerosols has not been considered in these studies. Table 3 includes the sensitivity tests conducted by using several convective schemes available in the EMAC model. The principal cases are shown in Fig. 9, whereas the other cases are shown in the Supplement (Fig. S4).

Figure 9 depicts the AOD time series for the stations shown in Fig. 3; it shows a larger sensitivity to the convection compared to the emission flux parameterizations (Sect. 4.1). In particular, the AOD is more sensitively influenced over western Africa than over the Caribbean sites, which is primarily a result of the decreasing dust burden due to the removal of the dust during transport (Fig. 6). Generally, the AOD is underestimated at all stations in the reference simulation (EMAC), except for Saada. From 20 to 25 July 2009, this significantly improves in the sensitivity simulations (B1T3 and B1T5). However, the model also simulates a dust outflow event that is not observed by the AERONET stations. Over the Caribbean, case B1T5 (ECMWF operational convection scheme) yields the best overall results for the dust outflow events. The main differences between the schemes appear in the tropical region, while the maximum difference is obtained during the boreal summer. For these conditions (location plus time), the EMAC reference setup is associated with a relatively large discrepancy in the precipitation amount (Tost et al., 2006b). As a result, the scavenging of aerosols, including dust particles, is overestimated due to the high precipitation rates. Consequently, this over-removal of the dust results in an underestimation of the AOD over the Caribbean.

Figure 10 illustrates this finding. The total cloud fraction, precipitation, dust surface concentration and the dust burden (monthly mean) are shown for the different convection parameterizations in comparison to the MODIS cloud fraction and the TRMM precipitation. In general, the model reproduces the main features of the cloud cover obser- 

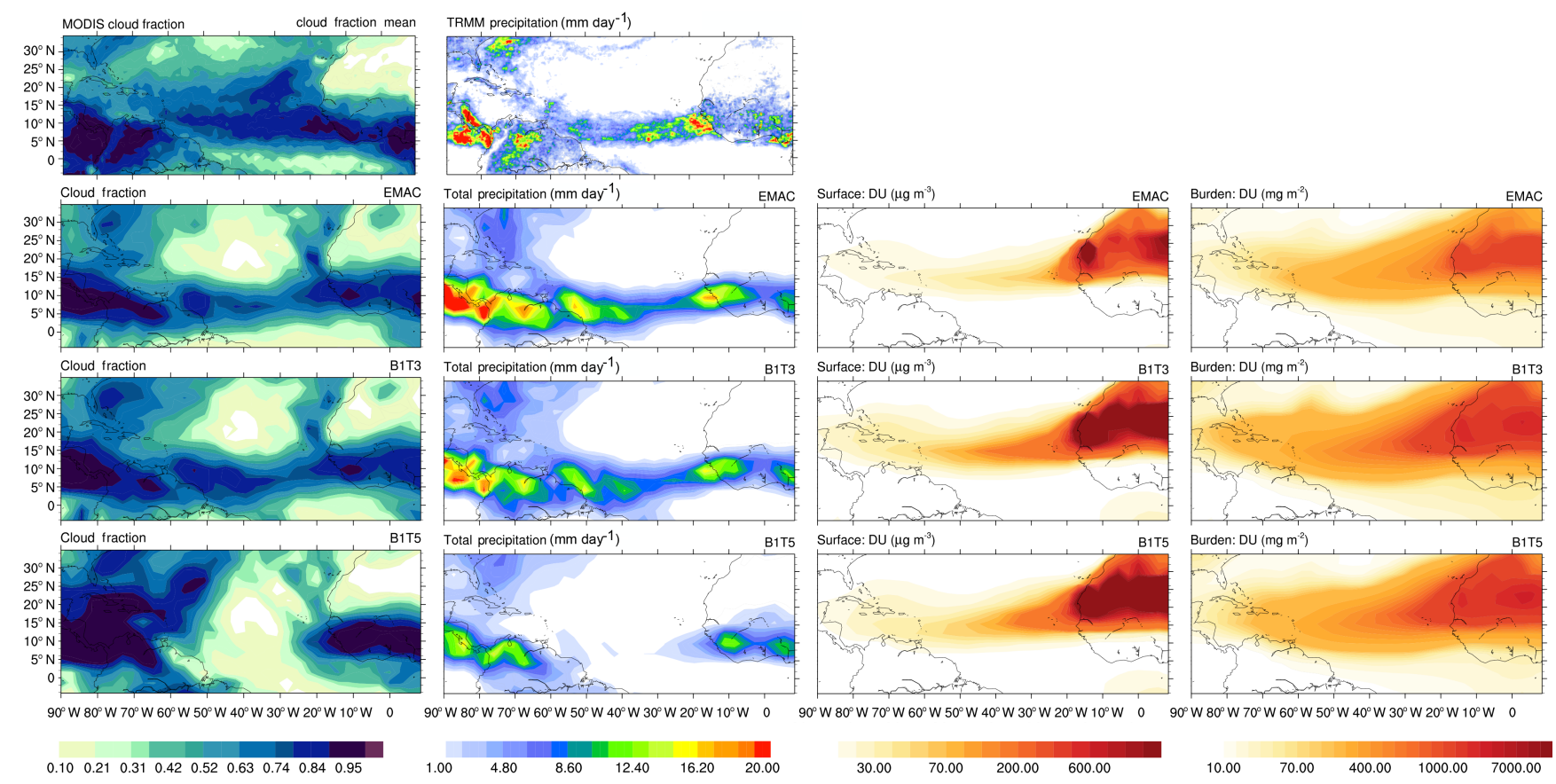

Figure 10. MODIS cloud fraction and TRMM precipitation (top; July 2009 monthly mean). EMAC results (below; from left to right) for the cloud fraction, precipitation, surface dust concentration and dust burden for the different convection schemes (second to fourth row) highlighted in Table 3. The model precipitation and cloud cover agree for our EMAC setup best with the TRMM and MODIS observations with the TIEDTKE (B1T3) and ECMWF (B1T5) convection schemes.

vations; however, EMAC (reference) underestimates cloud cover over the Atlantic Ocean. Over the tropical areas in Africa, B1T5 (ECMWF) leads to more realistic results compared to MODIS and compared to B1T4 (also ECMWF but with shallow convection closure, shown in Fig. S5 in the Supplement). Over the ocean, B1T5 considerably underestimates cloud cover and precipitation rates. Over the Caribbean sites, B1T5 overestimates cloud cover, whereas the other schemes produce more realistic results. The calculated precipitation (second column) generally shows an overestimation for all schemes except B1T5 with an underestimation over the ocean. As a result of the differences in the cloud cover and precipitation rates, all model simulations show different magnitudes of the dust plumes (third and fourth columns), which is most pronounced for the dust burden. For the reference simulation (EMAC in Table 3 and Fig. 10), the dust plume extends to $60^{\circ} \mathrm{W}$ with a dust burden of $200 \mathrm{mg} \mathrm{m}^{-2}$, whereas for simulation B1T3 (TIEDTKE), the same dust burden is obtained at $80^{\circ} \mathrm{W}$ and westward. The difference in the dust plume magnitude merely results from different removal efficiencies because of different precipitation rates.

For a quantitative comparison, the average meridional dust burden in the dust outflow over the Atlantic Ocean region $\left(10-25^{\circ} \mathrm{N}\right)$ is shown in Fig. 11 for different convection parameterizations. Additionally, the precipitation and the column-averaged aged dust proxy (ADP), which was in- troduced by Abdelkader et al. (2015), are included. The ADP simulations, which represent the ratio between the aged and non-aged dust particles, indicates the level of dust chemical aging (i.e., the mass fraction of the aged to the total dust mass). A 0 ADP value indicates "pristine" or freshly emitted insoluble particles (no aging), whereas a value of 1 indicates that all dust particles are chemically aged (fully coated and transfered from the insoluble to the soluble modes).

First, the dust burden shows a very steep gradient westward over the Atlantic Ocean. This is mainly a result of dust removal by deposition (sedimentation and scavenging mechanisms) during long-range transport. Over the Atlantic (within the DTA), this gradient is linear in the logarithmic scale, whereas the gradient is nonlinear over the western and eastern Atlantic (especially within the DIZ). The dust burden over western Africa (east of $10^{\circ} \mathrm{W}$ ) is about $1000 \mu \mathrm{g} \mathrm{m}^{-3}$ but

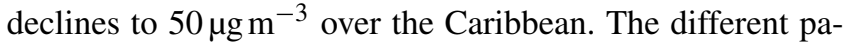
rameterization schemes show more than a factor of 2 difference between the dust burden over western Africa and about a factor of 3 over the Caribbean. This is primarily a result of different precipitation rates and the associated differences in dust removal. The two precipitation peaks (over western Africa and the Caribbean) shown in Fig. 5 are also seen in Fig. 11. They are, however, weaker because the averaging is performed over a wider area (dust plume) that is not associated with precipitation. The higher precipitation rate over the western and eastern parts of the Atlantic results in enhanced 


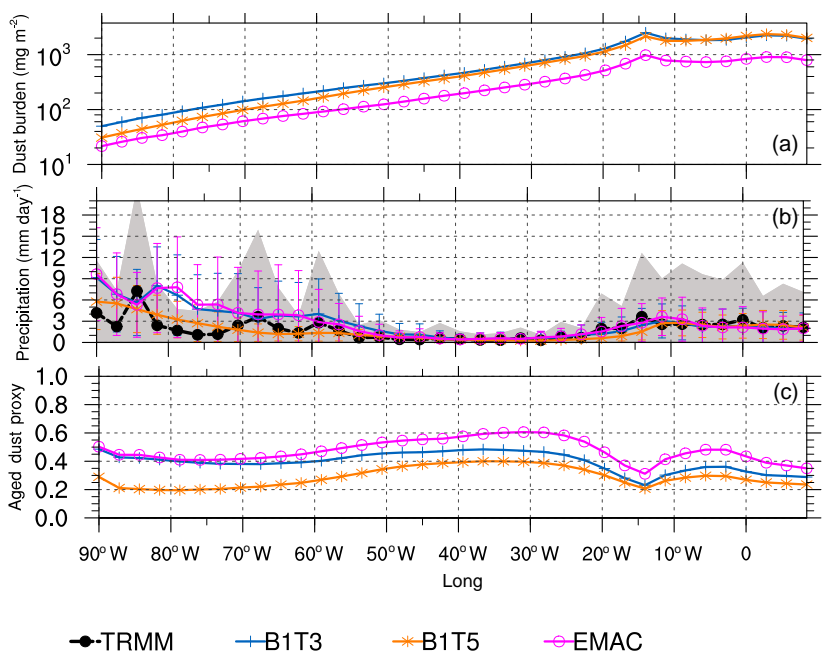

Figure 11. A comparison of the observed and calculated meridional means of the dust outflow over the Atlantic Ocean region $\left(10-25^{\circ} \mathrm{N}\right.$ ) for (top) dust burden, (middle) precipitation and (bottom) aged dust proxy (ADP) for July 2009 (monthly mean). The ADP represents the ratio between the aged and non-aged dust particles. The shaded area represents 1 standard deviation of the TRMM precipitation, and the bars show 1 standard deviation of the model results.

dust scavenging. Over the Atlantic, the precipitation is lower, and therefore the removal by sedimentation is stronger in July $2009\left(\approx 2 \mathrm{~g} \mathrm{~m}^{-2}\right.$ compared to $\left.\approx 0.2 \mathrm{~g} \mathrm{~m}^{-2}\right)$. The elevated precipitation over the Caribbean causes maximum wet deposition. As a result, the dust burden is an order of magnitude lower over the Caribbean compared to western Africa. In addition, there is a clear anticorrelation between the dust burden and the precipitation amount over both sides of the Atlantic. The comparison of precipitation with the TRMM observations reveals that the EMAC model gives more realistic results over western Africa compared with the Caribbean for all convection schemes.

Second, the ADP (Fig. 11) illustrates the effect of convection schemes on the transatlantic dust transport. Over western Africa, the dust is already aged with ADP values between 0.2 and 0.4, whereas over the Caribbean the ADP values are only slightly higher at 0.3 and 0.5 . The lower ADP values over western Africa can be attributed to the higher dust loading, which requires a much larger amount of condensable material to become fully aged. Over the Caribbean, the dust loading is considerably lower due to the removal processes along dust transport, which takes about 5 days. This time period is sufficiently long to allow for coating by acids and other soluble materials (Gläser et al., 2015) and causes the dust to become more aged. On the other hand, the high precipitation amount at $15^{\circ} \mathrm{W}$ over the western African region results in more scavenging of the aged dust particles compared with the pristine (non-aged) dust particles. This results in a decrease in the ADP values, which is in agreement with the results of Abdelkader et al. (2015). West of $15^{\circ} \mathrm{W}$, the dust is transported over the Atlantic into a region where precipitation is much lower (middle panels). Consequently, the level of chemical aging increases. The EMAC reference simulation (with precipitation that is too strong) therefore shows a higher ADP (0.35 compared to 0.2), which is a result of the lower dust burden mainly caused by an overly efficient wet removal.

Thus, the convection sensitivity analysis points to an overly strong removal mechanism of the mineral dust particles along transatlantic transport when the default convection scheme is used in EMAC. In addition, the level of dust chemical aging seems to control the efficiency of dust scavenging. Higher levels of aged dust and higher precipitation amounts significantly decrease the dust burden and thus the AOD over the Caribbean. This further suggests that modeling the transatlantic dust transport requires improved convection parameterization (i.e., more realistic precipitation rates) in parallel with a realistic representation of dust chemical aging.

\subsection{Dust chemical aging}

To further investigate the impact of the dust chemical aging on the transatlantic dust transport, this process was excluded for an additional sensitivity study. The level of dust chemical aging depends on the availability of condensable acids (see Sect. 2). For the "no aging" case, the condensation of acids on insoluble dust particles is excluded, which suppresses water uptake by dust particles. Figure 12 shows the AOD time series at the AERONET stations on both sides of the Atlantic for the two cases, aging and no aging. Generally, the aging case systematically shows a higher AOD compared to the no aging case, which emphasizes the importance of this process and the associated water uptake in agreement with the results of Abdelkader et al. (2015). However, the dust chemical aging has a stronger impact on the AOD over western Africa, especially at the Cape Verde and Dakar stations, during the two dust outbreaks discussed above. The aging case shows an AOD about 0.2 higher compared with the no aging case as a result of the larger particle size and the associated water uptake. This increases the scattering cross section and thus the AOD. Over the Caribbean, the dust chemical aging shows a smaller impact on the AOD; the aging case shows an AOD only about 0.05 higher because of the lower contribution of the dust to the overall AOD values (which includes the contribution of other aerosol species, such as sea salt). During the high dust outbreaks, the concentration of the soluble compounds required to coat such a large amount of dust is not available according to the EMAC model. The aged dust particles are removed more efficiently during transport, and relatively more uncoated dust particles reach the Caribbean. As a result, the dust chemical aging has a limited effect on the AOD over the Caribbean AERONET stations. 

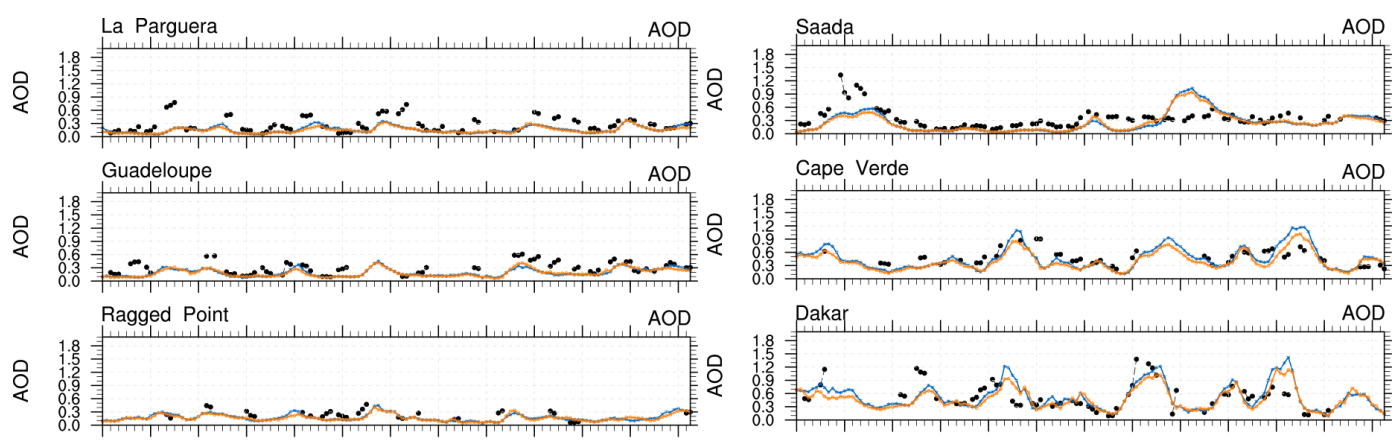

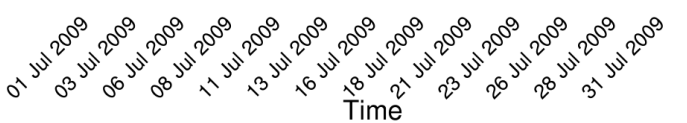

Caribbean

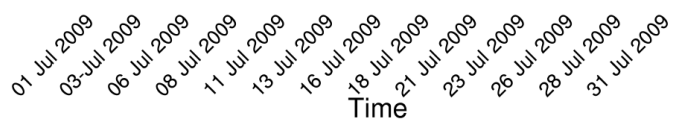

West Africa

\section{- AERONET $*$ Aging $\rightarrow$ No aging}

Figure 12. A comparison of the observed (AERONET) and calculated AOD for western Africa and the Caribbean and for two EMAC simulations that include and exclude chemical aging (labeled "aging" and "no aging", respectively).

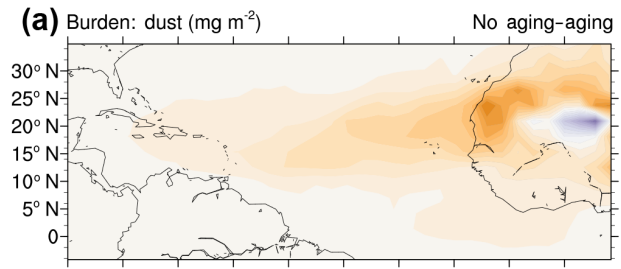

$90^{\circ} \mathrm{W} 80^{\circ} \mathrm{W} 70^{\circ} \mathrm{W} 60^{\circ} \mathrm{W} 50^{\circ} \mathrm{W} 40^{\circ} \mathrm{W} 30^{\circ} \mathrm{W} 20^{\circ} \mathrm{W} 10^{\circ} \mathrm{W} \quad 0$

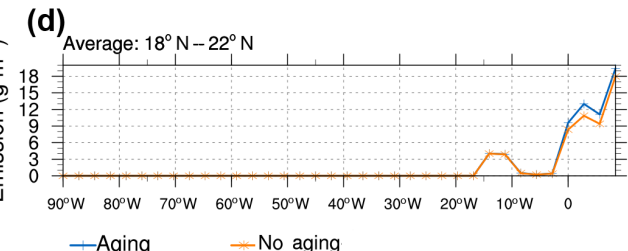

(b) $A O D$
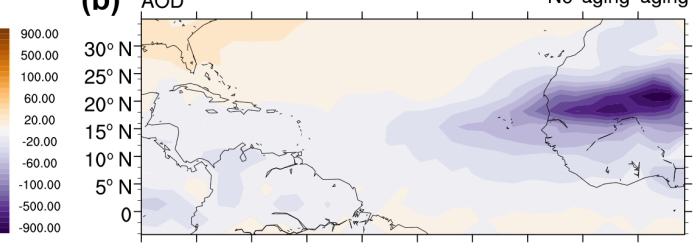

$90^{\circ} \mathrm{W} 80^{\circ} \mathrm{W} 70^{\circ} \mathrm{W} 60^{\circ} \mathrm{W} 50^{\circ} \mathrm{W} 40^{\circ} \mathrm{W} 30^{\circ} \mathrm{W} 20^{\circ} \mathrm{W} 10^{\circ} \mathrm{W}$

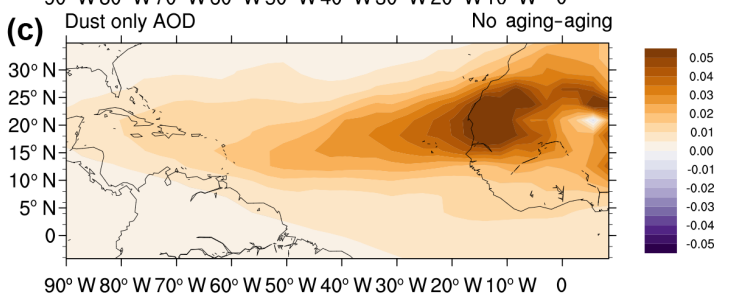

Figure 13. EMAC results (July 2009 monthly mean) for two simulations that include and exclude chemical aging (labeled "aging" and "no aging", respectively). The (a) difference in dust burden, (b) difference in AOD and (c) the dust emission averaged for the region from 18 to $22^{\circ} \mathrm{N}$ for both simulations. The (d) difference in "dust only AOD". "Aging" is the reference case. The difference shows the results of the "no aging" minus the "aging" case.

Figure 13 shows the regional difference (monthly mean) for (a) the dust burden, (b) the AOD, (c) the dust emissions averaged for the region from 18 to $22^{\circ} \mathrm{N}$ and (d) the dustonly AOD (no aging minus aging case). The results show a higher dust burden over the source regions in western Africa for the no aging case compared with the reference (aging). For the no aging case, the dust plume slightly extends further to the west over the Caribbean because of the reduced dust removal during transport. The difference between the two simulations decreases during transport, which is supported by the differences in the dust-only AOD. In contrast, the difference in the total AOD shows lower values over the dust source region compared with the aging case, which indicates a significant contribution of the dust chemical aging to the total AOD.

Interestingly, the negative feedback between the AOD and the radiation scheme results in a higher dust emission over the region from 10 to $0^{\circ} \mathrm{E}$ and thus causes a higher dust burden. The average dust emission in July 2009 over the region from 18 to $22^{\circ} \mathrm{N}$ (lower panel) shows that the dust emission for the aging case is higher on average by about $3 \mathrm{~g} \mathrm{~m}^{-2}$, which results in a higher dust burden by $1 \mathrm{~g} \mathrm{~m}^{-2}$ while the remaining amount of the dust $\left(2 \mathrm{~g} \mathrm{~m}^{-3}\right)$ is deposited. The higher AOD in the aging case results in a stronger scattering of shortwave solar radiation and lower surface radiation fluxes but a higher surface wind speed (as shown in Fig. S7 


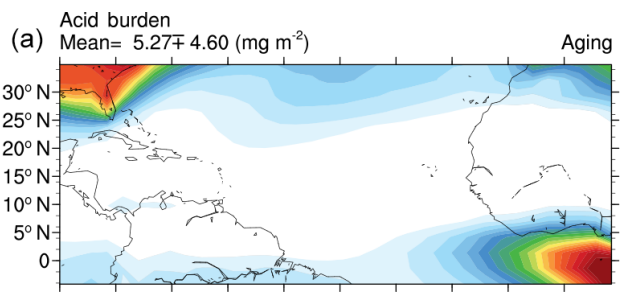

$90^{\circ} \mathrm{W} 80^{\circ} \mathrm{W} 70^{\circ} \mathrm{W} 60^{\circ} \mathrm{W} 50^{\circ} \mathrm{W} 40^{\circ} \mathrm{W} 30^{\circ} \mathrm{W} 20^{\circ} \mathrm{W} 10^{\circ} \mathrm{W} \quad 0$ Aerosol burden

(b) Mean $=21.00 \mp 28.03\left(\mathrm{mg} \mathrm{m}^{-2}\right)$

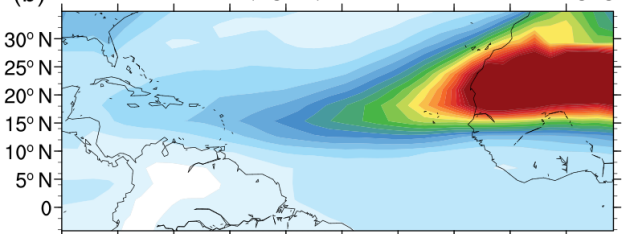

$90^{\circ} \mathrm{W} 80^{\circ} \mathrm{W} 70^{\circ} \mathrm{W} 60^{\circ} \mathrm{W} 50^{\circ} \mathrm{W} 40^{\circ} \mathrm{W} 30^{\circ} \mathrm{W} 20^{\circ} \mathrm{W} 10^{\circ} \mathrm{W} \quad 0$

(c) Burden: $\mathrm{H} 2 \mathrm{O}\left(\mathrm{mg} \mathrm{m}^{-2}\right)$

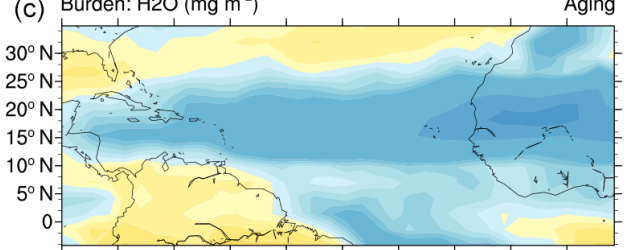

$90^{\circ} \mathrm{W} 80^{\circ} \mathrm{W} 70^{\circ} \mathrm{W} 60^{\circ} \mathrm{W} 50^{\circ} \mathrm{W} 40^{\circ} \mathrm{W} 30^{\circ} \mathrm{W} 20^{\circ} \mathrm{W} 10^{\circ} \mathrm{W} \quad 0$

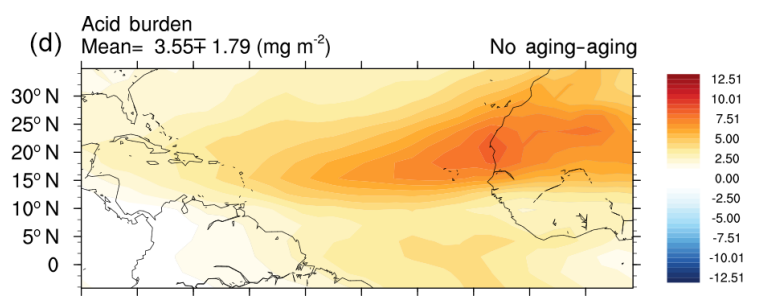

$90^{\circ} \mathrm{W} 80^{\circ} \mathrm{W} 70^{\circ} \mathrm{W} 60^{\circ} \mathrm{W} 50^{\circ} \mathrm{W} 40^{\circ} \mathrm{W} 30^{\circ} \mathrm{W} 20^{\circ} \mathrm{W} 10^{\circ} \mathrm{W} \quad 0$ Aerosol burden

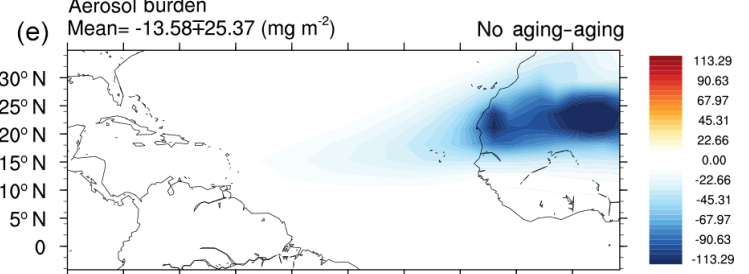

$90^{\circ} \mathrm{W} 80^{\circ} \mathrm{W} 70^{\circ} \mathrm{W} 60^{\circ} \mathrm{W} 50^{\circ} \mathrm{W} 40^{\circ} \mathrm{W} 30^{\circ} \mathrm{W} 20^{\circ} \mathrm{W} 10^{\circ} \mathrm{W} \quad 0$ Burden: $\mathrm{H} 2 \mathrm{O}\left(\mathrm{mg} \mathrm{m}^{-2}\right)$

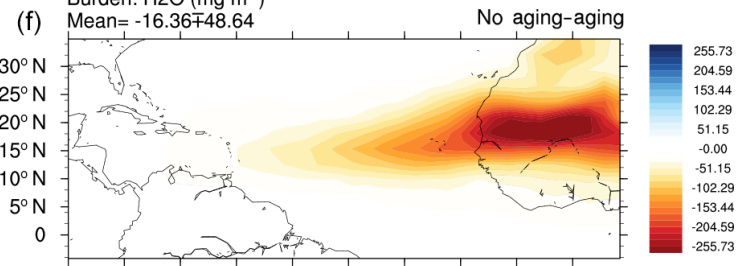

$90^{\circ} \mathrm{W} 80^{\circ} \mathrm{W} 70^{\circ} \mathrm{W} 60^{\circ} \mathrm{W} 50^{\circ} \mathrm{W} 40^{\circ} \mathrm{W} 30^{\circ} \mathrm{W} 20^{\circ} \mathrm{W} 10^{\circ} \mathrm{W} \quad 0$

Figure 14. Monthly mean (July 2009) for the (top) burden of lumped inorganic gas-phase acids $\left(\mathrm{HCl}+\mathrm{HNO}_{3}+\mathrm{H}_{2} \mathrm{SO}_{4}\right)$, the (middle) burden of lumped aerosols $\left(\mathrm{SO}_{4}^{2-}+\mathrm{HSO}_{4}^{-}+\mathrm{NO}_{3}^{-}+\mathrm{NH}_{4}^{+}+\mathrm{Cl}^{-}+\mathrm{Na}^{+}+\mathrm{Ca}^{2+}+\mathrm{K}^{+}+\mathrm{Mg}^{2+}\right.$ ) and the (bottom) burden of the aerosol-associated water mass (monthly mean). The left column is a reference simulation (aging case), and the right column is the difference between the reference and the no aging case. Note the inverted color scales for the bottom two panels, where the higher aerosol water mass is shown in blue and the lower is shown in red.

in the Supplement) and eventually a stronger dust emission of $2 \mathrm{~g} \mathrm{~m}^{-2}$. The increased wind speed (more than $0.25 \mathrm{~m} \mathrm{~s}^{-1}$, monthly average) could result either from the increase in the surface temperature because of the absorption of the dust particles and the resultant increase in the surface pressure (Menon, 2002; Mishra et al., 2014) or from a change in the horizontal temperature gradient that also increases the local wind speed (Rémy et al., 2015). On the other hand, the more efficient removal of the large dust particles in the aging case through both scavenging and sedimentation results in a lower dust burden and thus the lower AOD. The balance between the two competing processes defines the impact of dust chemical aging on AOD. The difference in the dust-only optical depth is shown in the lower right panel of Fig. 13 and indicates that the no aging case has a higher dust optical depth as a result of the lower dust removal compared with the aging case. The difference is at a minimum within the region between 18 and $22^{\circ} \mathrm{N}$. However, the total AOD shows that the no aging case leads to a lower AOD, which is significant over western Africa and less pronounced over the Caribbean sites. Note that the AOD shown in Fig. 12, as compared with the AERONET stations, does not resolve this large difference because the AERONET stations are all lo- cated in the DTA region where the differences are obviously lower.

The substantially higher AOD for the aging case $(0.3$ monthly mean) primarily results from the dust chemical aging because of the associated water uptake. Figure 14 shows the monthly averaged burden for lumped gas-phase acids $\left(\mathrm{HCl}+\mathrm{HNO}_{3}+\mathrm{H}_{2} \mathrm{SO}_{4}\right)$ and the difference between both simulations. The figure also shows the corresponding lumped inorganic aerosol mass $\left(\mathrm{SO}_{4}^{2-}+\mathrm{HSO}_{4}^{-}+\mathrm{NO}_{3}^{-}+\mathrm{NH}_{4}^{+}\right.$ $\left.+\mathrm{Cl}^{-}+\mathrm{Na}^{+}+\mathrm{Ca}^{2+}+\mathrm{K}^{+}+\mathrm{Mg}^{2+}\right)$ and the aerosolassociated water mass. For the aging case, the burden of acids is very low over the dust source region because of the uptake by dust particles; this is an important effect that has also been recently studied with the EMAC model by Karydis et al. (2016) for the nitric acid uptake (also included here). Consequently, the aerosol burden is higher over the dust source region and over the outflow region because of the additional neutralization of the calcium ions by anions and the associated absorption of water vapor by the resulting calcium salts. As a result, the aerosol-associated water increases by more than $255 \mathrm{mg} \mathrm{m}^{-2}$ for the aging case. The effect of dust chemical aging is a result of gas-aerosol partitioning that clearly affects the AOD. It is best observed in the differences (right column of Fig. 14), which reveal that the impact of dust 


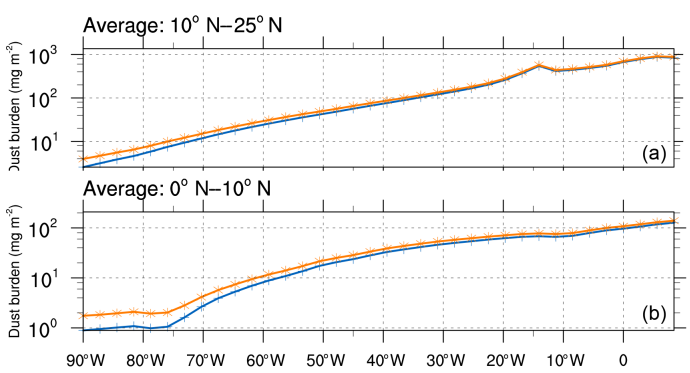

Dust burden

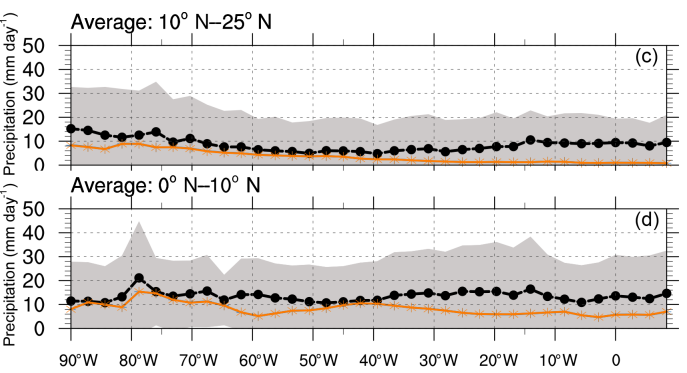

Precipitation

$\rightarrow$-TRMM $\quad$-Aging $\quad *$ No aging

Figure 15. The (left) dust burden and (right) precipitation for different regions: (top) dust transport over the Atlantic Ocean zone and (bottom) the dust-ITCZ zone from 0 to $10^{\circ} \mathrm{N}$. The shaded area represents 1 standard deviation of TRMM precipitation. The results show the long-term average of the entire evaluation period from 2000 to 2012.

chemical aging can be significant, mainly due to the associated uptake of aerosol water. We refer to this effect as the "direct effect of dust chemical aging." In addition, we refer to the higher removal of aged dust (by both sedimentation and scavenging) and the consequently shorter dust lifetime as the "indirect effect of dust chemical aging"; both effects are introduced in this study.

To obtain improved statistics for the effect of dust chemical aging, the same analysis (aging versus no aging) was applied to the entire evaluation period (2000-2012) at a lower T42 model resolution. Figure 15 shows the long-term meridional dust burden mean and the model precipitation for the TRMM observations over the DTA and DIR zones (as discussed above). The no aging case consistently shows higher dust burdens in the DIR zone as a result of more efficient scavenging for the aging case. Even for this long-term average, the dust burden is 3 times higher for the no aging case than the aging case over the Caribbean sites. However, the impact of scavenging in the aging case is stronger in the region between 10 and $20^{\circ} \mathrm{W}$, which corresponds with the precipitation peak in the western African region.

\section{Conclusions}

Transatlantic dust transport is a major large-scale atmospheric phenomenon. Although the EMAC model mostly reproduces the dust pattern during the transatlantic dust transport, the dust loadings and the AOD can deviate in magnitude and seasonality from observations. To examine the controlling processes, the dust outflow region has been divided into two subregions: (1) the dust-ITCZ (DIZ) zone and (2) the adjacent dust transport over the Atlantic Ocean (DTA) zone. In the former, the dust is removed primarily through scavenging, whereas in the latter region, sedimentation is predominant. Considering the two subregions allows for the distinction of the factors that affect the transatlantic dust transport.
Several sensitivity studies were conducted using the EMAC model following Abdelkader et al. (2015) with a comprehensive setup that includes a fully coupled online dust emission scheme and an explicit chemical aging of the atmospheric dust particles. First, the simulated AOD is sensitive to the emission flux parameterization, and even more sensitive to the choice of the convection scheme. The dust emission flux affects the AOD over western Africa more strongly compared to the Caribbean sites. On the other hand, the dust burden shows a very steep gradient westward over the Atlantic Ocean. This is mainly a result of dust removal through deposition (sedimentation and scavenging) during long-range transport. Over the Atlantic (within the DTA), this gradient is linear in the logarithmic scale, whereas the gradient is nonlinear over the western and eastern Atlantic (especially within the DIZ). The dust burden over western Africa (east of $10^{\circ} \mathrm{W}$ ) is about $1000 \mathrm{\mu g} \mathrm{m}^{-3}$ but declines to $50 \mu \mathrm{g} \mathrm{m}{ }^{-3}$ over the Caribbean. The different convection parameterization schemes show more than a factor of 2 difference in the dust burden over western Africa and about a factor of 3 over the Caribbean. This is primarily a result of different precipitation rates and the associated differences in dust removal. Overall, the dust outflow into the Caribbean is best represented by the ECMWF convection scheme as a result of a more realistic representation of precipitation within the ITCZ (compared to other schemes available in EMAC and relative to the TRMM observations). The more realistic precipitation improves the dust removal (compared to the reference EMAC simulations) and subsequently the AOD on both sides of the Atlantic Ocean significantly within the DIZ zone, a region which is largely controlled by wet removal processes. Considering the dust chemical aging amplifies this effect.

To study the impact of dust chemical aging, we use the calcium cation as a proxy for the overall chemical reactive dust fraction and consider the uptake of major inorganic acids (i.e., $\mathrm{H}_{2} \mathrm{SO}_{4}, \mathrm{HNO}_{3}$ and $\mathrm{HCl}$ ) and their anions, i.e., sulfate $\left(\mathrm{SO}_{4}^{2-}\right)$, bisulfate $\left(\mathrm{HSO}_{4}^{-}\right)$, nitrate $\left(\mathrm{NO}_{3}^{-}\right)$and chloride $\left(\mathrm{Cl}^{-}\right)$, on the surface of mineral particles. The subse- 
quent neutralization reactions with the calcium cation form various salt compounds that cause the uptake of water vapor from the atmosphere, which leads to the chemical aging of dust particles. Dust chemical aging changes the particle sizes because of the additional amount of condensed inorganic acids and the associated uptake of water vapor by the neutralization products (salts). Therefore, the aged dust particles are larger and scatter light more efficiently, whereas they are more rapidly removed through dry and wet removal processes. To analyze these effects, we performed aging and no aging simulations, for which we distinguish between the direct and indirect effect of dust chemical aging on AOD.

In our sensitivity simulations, the dust chemical aging shows the largest impact on the AOD over western Africa and on the dust burden in the ITCZ. The larger impact on the AOD results from the increase in the aerosol burden (more than $120 \mathrm{mg} \mathrm{m}^{-2}$ ) due to the uptake of acids and associated water by the originally insoluble dust particles. This directly increases the AOD by 0.15 (monthly average). As a result of the radiative feedback on the atmospheric dynamics and circulation, the dust emission increases regionally. On the other hand, the aged dust particles are more efficiently removed in our EMAC reference setup compared with the non-aged dust particles. The enhanced removal of aged particles decreases the dust burden and lifetime, indirectly affecting the AOD. Both processes are significant, and the net effect depends on the region and the level of dust chemical aging, which is controlled by the strength of the dust outflow and the collocated air pollution levels. In order to improve the dust cycle in climate models, we recommend an explicit treatment of dust chemical aging, at least by considering the calcium cation as a proxy for the overall chemical reactivity of the mineral dust particles.

Data availability. The underlying research data is available on request. 


\section{Appendix A: Evaluation metrics}

- RMSE; the root mean square error between the model (m) and the observations (o) calculated with

$\mathrm{RMSE}=\sqrt{\frac{1}{N} \sum\left(X_{\mathrm{m}}-X_{\mathrm{o}}\right)^{2}}$.

- $\sigma$; the standard deviation of the model $\left(\sigma_{\mathrm{m}}\right)$ and the observation $\left(\sigma_{0}\right)$ for variable $\left(X_{i}\right)$ with an average of $(\bar{X})$ with $N$ number of observations, calculated with

$\sigma=\sqrt{\frac{1}{N} \sum_{i=1}^{N}\left(X_{i}-\bar{X}\right)^{2}}$, where $\bar{X}=\frac{1}{N} \sum_{i=1}^{N} X_{i}$.

- $R$; the correlation coefficient between the model (m) and the observations (o) calculated with

$$
R=\frac{\sum_{i=1}^{N}\left(X_{i}^{\mathrm{m}}-\overline{X^{\mathrm{m}}}\right)\left(X_{i}^{\mathrm{o}}-\overline{X^{\mathrm{o}}}\right)}{\sum_{i=1}^{N}\left(X_{i}^{\mathrm{m}}-\overline{X^{\mathrm{m}}}\right)^{2} \sum_{i=1}^{N}\left(X_{i}^{\mathrm{o}}-\overline{X^{\mathrm{o}}}\right)^{2}} .
$$

- $r$; the geometric mean of the model $\left(r_{\mathrm{m}}\right)$ and the observations $\left(r_{\mathrm{O}}\right)$ calculated with

$r=\sqrt[n]{\Pi_{i=1}^{N} X}$

- MBE; the mean bias error between the model and the observations calculated with

$\mathrm{MBE}=\frac{1}{N} \sum\left(X_{\mathrm{m}}-X_{\mathrm{o}}\right)$.

- GFE; the growth factorial error calculated with

$\mathrm{GFE}=\frac{1}{N} \sum \frac{\left|\left(X_{\mathrm{m}}-X_{\mathrm{o}}\right)\right|}{X_{\mathrm{m}}+X_{\mathrm{o}}}$.

- SS1; the skill score between the model (m) and the observations (o) (Taylor, 2001) calculated with

$\mathrm{SS} 1=\frac{4(1+R)}{\left(\sigma_{\mathrm{f}}+1 / \sigma_{\mathrm{f}}\right)^{2}\left(1+R_{0}\right)}$, where $\sigma_{\mathrm{f}}=\frac{\sigma_{\mathrm{o}}}{\sigma_{\mathrm{m}}} \quad R_{0}=0.0$. 
Competing interests. The authors declare that they have no conflict of interest.

Acknowledgements. All simulations in this study were carried out on the Cy-Tera cluster. The Cy-Tera project (NEA-Y П О $\Delta$ $\mathrm{OMH} / \Sigma$ TPATH/0308/31) is cofinanced by the European Regional Development Fund and the Republic of Cyprus through the Research Promotion Foundation. This study received funding from the European Research Council under the European Union's Seventh Framework Programme (FP7; 2007-2013; ERC grant agreement no. 226144). The authors are grateful to NASA and PHOTONS (PHOtométrie pour le Traitement Opérationnel de Normalisation Satellitaire; Univ. of Lille 1, CNES and CNRS-INSU), a federation of ground-based remote-sensing aerosol networks that establish the AErosol RObotic NETwork program (http://aeronet.gsfc.nasa.gov), for the AERONET data used in this study. Georgiy Stenchikov is supported by the King Abdullah University of Science and Technology (KAUST) CRG3 grant. This work was performed at the The Cyprus Institute.

The article processing charges for this open-access publication were covered by the Max Planck Society.

Edited by: M. Kanakidou

Reviewed by: three anonymous referees

\section{References}

Abdelkader, M., Metzger, S., Mamouri, R. E., Astitha, M., Barrie, L., Levin, Z., and Lelieveld, J.: Dust-air pollution dynamics over the eastern Mediterranean, Atmos. Chem. Phys., 15, 9173-9189, doi:10.5194/acp-15-9173-2015, 2015.

Abouchami, W., Näthe, K., Kumar, A., Galer, S. J., Jochum, K. P., Williams, E., Horbe, A. M., Rosa, J. W., Balsam, W., Adams, D., Mezger, K., and Andreae, M. O.: Geochemical and isotopic characterization of the Bodélé Depression dust source and implications for transatlantic dust transport to the Amazon Basin, Earth Planet. Sci. Lett., 380, 112-123, doi:10.1016/j.epsl.2013.08.028, 2013.

Adams, A. M., Prospero, J. M., and Zhang, C.: CALIPSODerived Three-Dimensional Structure of Aerosol over the Atlantic Basin and Adjacent Continents, J. Climate, 25, 6862-6879, doi:10.1175/JCLI-D-11-00672.1, 2012.

Alexander, J. M., Grassian, V. H., Young, M. A., and Kleiber, P. D.: Optical properties of selected components of mineral dust aerosol processed with organic acids and humic material: Optical Properties of Mineral Dust, J. Geophys. Res.-Atmos., 120, 2437-2452, doi:10.1002/2014JD022782, 2015.

Alizadeh-Choobari, O., Sturman, A., and Zawar-Reza, P.: A global satellite view of the seasonal distribution of mineral dust and its correlation with atmospheric circulation, Dynam. Atmos. Oceans, 68, 20-34, doi:10.1016/j.dynatmoce.2014.07.002, 2014.

Astitha, M., Kallos, G., Spyrou, C., O'Hirok, W., Lelieveld, J., and Denier van der Gon, H. A. C.: Modelling the chemically aged and mixed aerosols over the eastern central Atlantic Ocean - potential impacts, Atmos. Chem. Phys., 10, 5797-5822, doi:10.5194/acp-10-5797-2010, 2010.
Astitha, M., Lelieveld, J., Abdel Kader, M., Pozzer, A., and de Meij, A.: Parameterization of dust emissions in the global atmospheric chemistry-climate model EMAC: impact of nudging and soil properties, Atmos. Chem. Phys., 12, 11057-11083, doi:10.5194/acp-12-11057-2012, 2012.

Baker, A. R., Lesworth, T., Adams, C., Jickells, T. D., and Ganzeveld, L.: Estimation of atmospheric nutrient inputs to the Atlantic Ocean from $50^{\circ} \mathrm{N}$ to $50^{\circ} \mathrm{S}$ based on large-scale field sampling: Fixed nitrogen and dry deposition of phosphorus: ATLANTIC ATMOSPHERIC NUTRIENT INPUTS, Global Biogeochem. Cy., 24, doi:10.1029/2009GB003634, 2010.

Baker, A. R., Adams, C., Bell, T. G., Jickells, T. D., and Ganzeveld, L.: Estimation of atmospheric nutrient inputs to the Atlantic Ocean from $50^{\circ} \mathrm{N}$ to $50^{\circ} \mathrm{S}$ based on large-scale field sampling: Iron and other dust-associated elements: ATLANTIC ATMOSPHERIC IRON INPUTS, Global Biogeochem. Cy., 27, 755767, doi:10.1002/gbc.20062, 2013.

Bangalath, H. K. and Stenchikov, G.: Role of dust direct radiative effect on the tropical rain belt over Middle East and North Africa: A high-resolution AGCM study: DUST RADIATIVE EFFECT OVER MENA, J. Geophys. Res.-Atmos., 120, 45644584, doi:10.1002/2015JD023122, 2015.

Bauer, S. E., Mishchenko, M. I., Lacis, A. A., Zhang, S., Perlwitz, J., and Metzger, S. M.: Do sulfate and nitrate coatings on mineral dust have important effects on radiative properties and climate modeling?, J. Geophys. Res.-Atmos., 112, D06307, doi:10.1029/2005JD006977, 2007.

Bechtold, P., Chaboureau, J.-P., Beljaars, A., Betts, A. K., Köhler, M., Miller, M., and Redelsperger, J.-L.: The simulation of the diurnal cycle of convective precipitation over land in a global model, Q. J. Roy. Meteorol. Soc., 130, 3119-3137, doi:10.1256/qj.03.103, 2004.

Ben-Ami, Y., Koren, I., and Altaratz, O.: Patterns of North African dust transport over the Atlantic: winter vs. summer, based on CALIPSO first year data, Atmos. Chem. Phys., 9, 7867-7875, doi:10.5194/acp-9-7867-2009, 2009.

Ben-Ami, Y., Koren, I., Rudich, Y., Artaxo, P., Martin, S. T., and Andreae, M. O.: Transport of North African dust from the Bodélé depression to the Amazon Basin: a case study, Atmos. Chem. Phys., 10, 7533-7544, doi:10.5194/acp-10-7533-2010, 2010.

Ben-Ami, Y., Koren, I., Altaratz, O., Kostinski, A., and Lehahn, Y.: Discernible rhythm in the spatio/temporal distributions of transatlantic dust, Atmos. Chem. Phys., 12, 2253-2262, doi:10.5194/acp-12-2253-2012, 2012.

Bristow, C. S., Hudson-Edwards, K. A., and Chappell, A.: Fertilizing the Amazon and equatorial Atlantic with West African dust: AFRICAN FERTILIZER FOR AMAZON AND ATLANTIC, Geophys. Res. Lett., 37, L14807, doi:10.1029/2010GL043486, 2010.

Chin, M., Diehl, T., Tan, Q., Prospero, J. M., Kahn, R. A., Remer, L. A., Yu, H., Sayer, A. M., Bian, H., Geogdzhayev, I. V., Holben, B. N., Howell, S. G., Huebert, B. J., Hsu, N. C., Kim, D., Kucsera, T. L., Levy, R. C., Mishchenko, M. I., Pan, X., Quinn, P. K., Schuster, G. L., Streets, D. G., Strode, S. A., Torres, O., and Zhao, X.-P.: Multi-decadal aerosol variations from 1980 to 2009: a perspective from observations and a global model, Atmos. Chem. Phys., 14, 3657-3690, doi:10.5194/acp-14-3657-2014, 2014.

Cuevas, E., Camino, C., Benedetti, A., Basart, S., Terradellas, E., Baldasano, J. M., Morcrette, J. J., Marticorena, B., Goloub, 
P., Mortier, A., Berjón, A., Hernández, Y., Gil-Ojeda, M., and Schulz, M.: The MACC-II 2007-2008 reanalysis: atmospheric dust evaluation and characterization over northern Africa and the Middle East, Atmos. Chem. Phys., 15, 3991-4024, doi:10.5194/acp-15-3991-2015, 2015.

Darmenova, K., Sokolik, I. N., Shao, Y., Marticorena, B., and Bergametti, G.: Development of a physically based dust emission module within the Weather Research and Forecasting (WRF) model: Assessment of dust emission parameterizations and input parameters for source regions in Central and East Asia, J. Geophys. Res., 114, D14201, doi:10.1029/2008JD011236, 2009.

Diner, D., Beckert, J., Reilly, T., Bruegge, C., Conel, J., Kahn, R., Martonchik, J., Ackerman, T., Davies, R., Gerstl, S., Gordon, H., Muller, J., Myneni, R., Sellers, P., Pinty, B., and Verstraete, M.: Multi-angle Imaging SpectroRadiometer (MISR) instrument description and experiment overview, IEEE T. Geosci. Remote, 36, 1072-1087, doi:10.1109/36.700992, 1998.

Fountoukis, C. and Nenes, A.: ISORROPIA II: a computationally efficient thermodynamic equilibrium model for $\mathrm{K}^{+}$$\mathrm{Ca}^{2+}-\mathrm{Mg}^{2+}-\mathrm{NH}_{4}^{+}-\mathrm{Na}^{+}-\mathrm{SO}_{4}^{2-}-\mathrm{NO}_{3}^{-}-\mathrm{Cl}^{-}-\mathrm{H}_{2} \mathrm{O}$ aerosols, Atmos. Chem. Phys., 7, 4639-4659, doi:10.5194/acp-7-4639-2007, 2007.

Ginoux, P., Prospero, J., Torres, O., and Chin, M.: Long-term simulation of global dust distribution with the GOCART model: correlation with North Atlantic Oscillation, Environ. Model. Softw., 19, 113-128, doi:10.1016/S1364-8152(03)00114-2, 2004.

Gläser, G., Wernli, H., Kerkweg, A., and Teubler, F.: The transatlantic dust transport from North Africa to the Americas-Its characteristics and source regions: TRANSATLANTIC DUST TRANSPORT, J. Geophys. Res.-Atmos., 120, 11231-11252, doi:10.1002/2015JD023792, 2015.

Gläser, G., Kerkweg, A., and Wernli, H.: The Mineral Dust Cycle in EMAC 2.40: sensitivity to the spectral resolution and the dust emission scheme, Atmos. Chem. Phys., 12, 1611-1627, doi:10.5194/acp-12-1611-2012, 2012.

Grant, A. L. M. and Brown, A. R.: A similarity hypothesis for shallow-cumulus transports, Q. J. Roy. Meteorol. Soc., 125, 1913-1936, doi:10.1002/qj.49712555802, 1999.

Groß, S., Freudenthaler, V., Schepanski, K., Toledano, C., Schäfler, A., Ansmann, A., and Weinzierl, B.: Optical properties of longrange transported Saharan dust over Barbados as measured by dual-wavelength depolarization Raman lidar measurements, Atmos. Chem. Phys., 15, 11067-11080, doi:10.5194/acp-1511067-2015, 2015.

Guo, Y., Tian, B., Kahn, R. A., Kalashnikova, O., Wong, S., and Waliser, D. E.: Tropical Atlantic dust and smoke aerosol variations related to the Madden-Julian Oscillation in MODIS and MISR observations: ATLANTIC DUST AND SMOKE, J. Geophys. Res.-Atmos., 118, 4947-4963, doi:10.1002/jgrd.50409, 2013.

Hack, J. J.: Parameterization of moist convection in the National Center for Atmospheric Research community climate model (CCM2), J. Geophys. Res.-Atmos., 99, 5551-5568, doi:10.1029/93JD03478, 1994.

Holben, B., Eck, T., Slutsker, I., Tanré, D., Buis, J., Setzer, A., Vermote, E., Reagan, J., Kaufman, Y., Nakajima, T., Lavenu, F., Jankowiak, I., and Smirnov, A.: AERONET - A Federated Instrument Network and Data Archive for Aerosol Character- ization, Remote Sens. Environ., 66, 1-16, doi:10.1016/S00344257(98)00031-5, 1998.

Hsu, N. C., Gautam, R., Sayer, A. M., Bettenhausen, C., Li, C., Jeong, M. J., Tsay, S.-C., and Holben, B. N.: Global and regional trends of aerosol optical depth over land and ocean using SeaWiFS measurements from 1997 to 2010, Atmos. Chem. Phys., 12, 8037-8053, doi:10.5194/acp-12-8037-2012, 2012.

Huang, J., Zhang, C., and Prospero, J. M.: Aerosol-Induced LargeScale Variability in Precipitation over the Tropical Atlantic, J. Climate, 22, 4970-4988, doi:10.1175/2009JCLI2531.1, 2009.

Huang, J., Zhang, C., and Prospero, J. M.: African dust outbreaks: A satellite perspective of temporal and spatial variability over the tropical Atlantic Ocean, J. Geophys. Res., 115, doi:10.1029/2009JD012516, 2010.

Huneeus, N., Schulz, M., Balkanski, Y., Griesfeller, J., Prospero, J., Kinne, S., Bauer, S., Boucher, O., Chin, M., Dentener, F., Diehl, T., Easter, R., Fillmore, D., Ghan, S., Ginoux, P., Grini, A., Horowitz, L., Koch, D., Krol, M. C., Landing, W., Liu, X., Mahowald, N., Miller, R., Morcrette, J.-J., Myhre, G., Penner, J., Perlwitz, J., Stier, P., Takemura, T., and Zender, C. S.: Global dust model intercomparison in AeroCom phase I, Atmos. Chem. Phys., 11, 7781-7816, doi:10.5194/acp-11-7781-2011, 2011.

Jickells, T. D., An, Z. S., Andersen, K. K., Baker, A. R., Bergametti, G., Brooks, N., Cao, J. J., Boyd, P. W., Duce, R. A., Hunter, K. A., Kawahata, H., Kubilay, N., laRoche, J., Liss, P. S., Mahowald, N., Prospero, J. M., Ridgwell, A. J., Tegen, I., and Torres, R.: Global Iron Connections Between Desert Dust, Ocean Biogeochemistry, and Climate, Science, 308, 67-71, 2005.

Jöckel, P., Tost, H., Pozzer, A., Brühl, C., Buchholz, J., Ganzeveld, L., Hoor, P., Kerkweg, A., Lawrence, M. G., Sander, R., Steil, B., Stiller, G., Tanarhte, M., Taraborrelli, D., van Aardenne, J., and Lelieveld, J.: The atmospheric chemistry general circulation model ECHAM5/MESSy1: consistent simulation of ozone from the surface to the mesosphere, Atmos. Chem. Phys., 6, 50675104, doi:10.5194/acp-6-5067-2006, 2006.

Jöckel, P., Kerkweg, A., Pozzer, A., Sander, R., Tost, H., Riede, H., Baumgaertner, A., Gromov, S., and Kern, B.: Development cycle 2 of the Modular Earth Submodel System (MESSy2), Geosci. Model Dev., 3, 717-752, doi:10.5194/gmd-3-717-2010, 2010.

Karydis, V. A., Tsimpidi, A. P., Pozzer, A., Astitha, M., and Lelieveld, J.: Effects of mineral dust on global atmospheric nitrate concentrations, Atmos. Chem. Phys., 16, 1491-1509, doi:10.5194/acp-16-1491-2016, 2016.

Kaufman, Y. J.: Dust transport and deposition observed from the Terra-Moderate Resolution Imaging Spectroradiometer (MODIS) spacecraft over the Atlantic Ocean, J. Geophys. Res., 110, D10S12, doi:10.1029/2003JD004436, 2005.

Kaufman, Y. J., Tanré, D., Remer, L. A., Vermote, E. F., Chu, A., and Holben, B. N.: Operational remote sensing of tropospheric aerosol over land from EOS moderate resolution imaging spectroradiometer, J. Geophys. Res., 102, 17051, doi:10.1029/96JD03988, 1997.

Kerkweg, A., Buchholz, J., Ganzeveld, L., Pozzer, A., Tost, H., and Jöckel, P.: Technical Note: An implementation of the dry removal processes DRY DEPosition and SEDImentation in the Modular Earth Submodel System (MESSy), Atmos. Chem. Phys., 6, 4617-4632, doi:10.5194/acp-6-4617-2006, 2006a.

Kerkweg, A., Sander, R., Tost, H., and Jöckel, P.: Technical note: Implementation of prescribed (OFFLEM), calculated (ON- 
LEM), and pseudo-emissions (TNUDGE) of chemical species in the Modular Earth Submodel System (MESSy), Atmos. Chem. Phys., 6, 3603-3609, doi:10.5194/acp-6-3603-2006, 2006b.

Khan, B., Stenchikov, G., Weinzierl, B., Kalenderski, S., and Osipov, S.: Dust plume formation in the free troposphere and aerosol size distribution during the Saharan Mineral Dust Experiment in North Africa, Tellus B, 67, 27170, doi:10.3402/tellusb.v67.27170, 2015.

Kim, D., Chin, M., Yu, H., Diehl, T., Tan, Q., Kahn, R. A., Tsigaridis, K., Bauer, S. E., Takemura, T., Pozzoli, L., Bellouin, N., Schulz, M., Peyridieu, S., Chédin, A., and Koffi, B.: Sources, sinks, and transatlantic transport of North African dust aerosol: A multimodel analysis and comparison with remote sensing data, J. Geophys. Res.-Atmos., 119, 6259-6277, doi:10.1002/2013JD021099, 2014.

Klingmüller, K., Steil, B., Brühl, C., Tost, H., and Lelieveld, J.: Sensitivity of aerosol radiative effects to different mixing assumptions in the AEROPT 1.0 submodel of the EMAC atmosphericchemistry-climate model, Geosci. Model Dev., 7, 2503-2516, doi:10.5194/gmd-7-2503-2014, 2014.

Lance, S., Raatikainen, T., Onasch, T. B., Worsnop, D. R., Yu, X.-Y., Alexander, M. L., Stolzenburg, M. R., McMurry, P. H., Smith, J. N., and Nenes, A.: Aerosol mixing state, hygroscopic growth and cloud activation efficiency during MIRAGE 2006, Atmos. Chem. Phys., 13, 5049-5062, doi:10.5194/acp-13-5049-2013, 2013.

Landgraf, J. and Crutzen, P. J.: An Efficient Method for Online Calculations of Photolysis and Heating Rates, J. Atmos. Sci., 55, 863-878, doi:10.1175/15200469(1998)055<0863:AEMFOC>2.0.CO;2, 1998.

Lauer, A., Eyring, V., Hendricks, J., Jöckel, P., and Lohmann, U.: Global model simulations of the impact of ocean-going ships on aerosols, clouds, and the radiation budget, Atmos. Chem. Phys., 7, 5061-5079, doi:10.5194/acp-7-5061-2007, 2007.

Li, W., Shao, L., Shi, Z., Chen, J., Yang, L., Yuan, Q., Yan, C., Zhang, X., Wang, Y., Sun, J., Zhang, Y., Shen, X., and Wang, Z. W.: Mixing State and Hygroscopicity of Dust and Haze Particles Before Leaving Asian Continent: INDIVIDUAL PARTICLES IN ASIAN OUTFLOW, J. Geophys. Res.-Atmos., 119, 1044-1059, doi:10.1002/2013JD021003, 2013.

Li, W. J. and Shao, L. Y.: Observation of nitrate coatings on atmospheric mineral dust particles, Atmos. Chem. Phys., 9, 18631871, doi:10.5194/acp-9-1863-2009, 2009.

Liu, C., Chu, B., Liu, Y., Ma, Q., Ma, J., He, H., Li, J., and Hao, J.: Effect of mineral dust on secondary organic aerosol yield and aerosol size in $\alpha$-pinene/NOx photo-oxidation, Atmos. Environ., 77, 781-789, doi:10.1016/j.atmosenv.2013.05.064, 2013.

Liu, Z., Omar, A., Vaughan, M., Hair, J., Kittaka, C., Hu, Y., Powell, K., Trepte, C., Winker, D., Hostetler, C., Ferrare, R., and Pierce, R.: CALIPSO lidar observations of the optical properties of Saharan dust: A case study of long-range transport, J. Geophys. Res.-Atmos., 113, D07207, doi:10.1029/2007JD008878, 2008.

Mahowald, N. M.: Anthropocene changes in desert area: Sensitivity to climate model predictions, Geophys. Res. Lett., 34, L18817, doi:10.1029/2007GL030472, 2007.

Mahowald, N. M., Kloster, S., Engelstaedter, S., Moore, J. K., Mukhopadhyay, S., McConnell, J. R., Albani, S., Doney, S. C., Bhattacharya, A., Curran, M. A. J., Flanner, M. G., Hoffman, F. M., Lawrence, D. M., Lindsay, K., Mayewski, P. A., Neff, J., Rothenberg, D., Thomas, E., Thornton, P. E., and Zender, C. S.:
Observed 20th century desert dust variability: impact on climate and biogeochemistry, Atmos. Chem. Phys., 10, 10875-10893, doi:10.5194/acp-10-10875-2010, 2010.

Marticorena, B. and Bergametti, G.: Modeling the atmospheric dust cycle: 1 . Design of a soil-derived dust emission scheme, J. Geophys. Res., 100, 16415-16430, doi:10.1029/95JD00690, 1995.

Menon, S.: Climate Effects of Black Carbon Aerosols in China and India, Science, 297, 2250-2253, doi:10.1126/science.1075159, 2002.

Metzger, S., Mihalopoulos, N., and Lelieveld, J.: Importance of mineral cations and organics in gas-aerosol partitioning of reactive nitrogen compounds: case study based on MINOS results, Atmos. Chem. Phys., 6, 2549-2567, doi:10.5194/acp-6-25492006, 2006.

Metzger, S., Steil, B., Abdelkader, M., Klingmüller, K., Xu, L., Penner, J. E., Fountoukis, C., Nenes, A., and Lelieveld, J.: Aerosol water parameterisation: a single parameter framework, Atmos. Chem. Phys., 16, 7213-7237, doi:10.5194/acp-16-7213-2016, 2016.

Mishra, A. K., Klingmueller, K., Fredj, E., Lelieveld, J., Rudich, Y., and Koren, I.: Radiative signature of absorbing aerosol over the eastern Mediterranean basin, Atmos. Chem. Phys., 14, 72137231, doi:10.5194/acp-14-7213-2014, 2014.

Möhler, O., Benz, S., Saathoff, H., Schnaiter, M., Wagner, R., Schneider, J., Walter, S., Ebert, V., and Wagner, S.: The effect of organic coating on the heterogeneous ice nucleation efficiency of mineral dust aerosols, Environ. Res. Lett., 3, 025007, doi:10.1088/1748-9326/3/2/025007, 2008.

Muhs, D. R., Budahn, J. R., Prospero, J. M., and Carey, S. N.: Geochemical evidence for African dust inputs to soils of western Atlantic islands: Barbados, the Bahamas, and Florida, J. Geophys. Res., 112, F02009, doi:10.1029/2005JF000445, 2007.

Muhs, D. R., Budahn, J. R., Prospero, J. M., Skipp, G., and Herwitz, S. R.: Soil genesis on the island of Bermuda in the Quaternary: The importance of African dust transport and deposition, J. Geophys. Res., 117, F03025, doi:10.1029/2012JF002366, 2012.

Nenes, A., Krom, M. D., Mihalopoulos, N., Van Cappellen, P., Shi, Z., Bougiatioti, A., Zarmpas, P., and Herut, B.: Atmospheric acidification of mineral aerosols: a source of bioavailable phosphorus for the oceans, Atmos. Chem. Phys., 11, 6265-6272, doi:10.5194/acp-11-6265-2011, 2011.

Nowottnick, E., Colarco, P., Ferrare, R., Chen, G., Ismail, S., Anderson, B., and Browell, E.: Online simulations of mineral dust aerosol distributions: Comparisons to NAMMA observations and sensitivity to dust emission parameterization, J. Geophys. Res., 115, D03202, doi:10.1029/2009JD012692, 2010.

Pozzer, A., de Meij, A., Pringle, K. J., Tost, H., Doering, U. M., van Aardenne, J., and Lelieveld, J.: Distributions and regional budgets of aerosols and their precursors simulated with the EMAC chemistry-climate model, Atmos. Chem. Phys., 12, 961-987, doi:10.5194/acp-12-961-2012, 2012.

Pozzer, A., de Meij, A., Yoon, J., Tost, H., Georgoulias, A. K., and Astitha, M.: AOD trends during 2001-2010 from observations and model simulations, Atmos. Chem. Phys., 15, 5521-5535, doi:10.5194/acp-15-5521-2015, 2015.

Pringle, K. J., Tost, H., Message, S., Steil, B., Giannadaki, D., Nenes, A., Fountoukis, C., Stier, P., Vignati, E., and Lelieveld, J.: Description and evaluation of GMXe: a new aerosol submodel 
for global simulations (v1), Geosci. Model Dev., 3, 391-412, doi:10.5194/gmd-3-391-2010, 2010.

Prospero, J. M., Landing, W. M., and Schulz, M.: African dust deposition to Florida: Temporal and spatial variability and comparisons to models, J. Geophys. Res., 115, D13304, doi:10.1029/2009JD012773, 2010.

Prospero, J. M., Collard, F.-X., Molinié, J., and Jeannot, A.: Characterizing the annual cycle of African dust transport to the Caribbean Basin and South America and its impact on the environment and air quality: African dust transport to South America, Global Biogeochem. Cy., 28, 757-773, doi:10.1002/2013GB004802, 2014.

Rémy, S., Benedetti, A., Bozzo, A., Haiden, T., Jones, L., Razinger, M., Flemming, J., Engelen, R. J., Peuch, V. H., and Thepaut, J. N.: Feedbacks of dust and boundary layer meteorology during a dust storm in the eastern Mediterranean, Atmos. Chem. Phys., 15, 12909-12933, doi:10.5194/acp-15-12909-2015, 2015.

Ridley, D. A., Heald, C. L., Pierce, J. R., and Evans, M. J.: Toward resolution-independent dust emissions in global models: Impacts on the seasonal and spatial distribution of dust: RESOLUTIONINDEPENDENT DUST EMISSIONS, Geophys. Res. Lett., 40, 2873-2877, doi:10.1002/grl.50409, 2013.

Roeckner, E., Brokopf, R., Esch, M., Giorgetta, M., Hagemann, S., Kornblueh, L., Manzini, E., Schlese, U., and Schulzweida, U.: Sensitivity of Simulated Climate to Horizontal and Vertical Resolution in the ECHAM5 Atmosphere Model, J. Climate, 19, 3771-3791, doi:10.1175/JCLI3824.1, 2006.

Rybka, H. and Tost, H.: Uncertainties in future climate predictions due to convection parameterisations, Atmos. Chem. Phys., 14, 5561-5576, doi:10.5194/acp-14-5561-2014, 2014.

Sander, R., Kerkweg, A., Jöckel, P., and Lelieveld, J.: Technical note: The new comprehensive atmospheric chemistry module MECCA, Atmos. Chem. Phys., 5, 445-450, doi:10.5194/acp-5445-2005, 2005.

Schlosser, C., Klar, J. K., Wake, B. D., Snow, J. T., Honey, D. J., Woodward, E. M. S., Lohan, M. C., Achterberg, E. P., and Moore, C. M.: Seasonal ITCZ migration dynamically controls the location of the (sub)tropical Atlantic biogeochemical divide, P. Natl. Acad. Sci., 111, 1438-1442, doi:10.1073/pnas.1318670111, 2014.

Schulz, M., Prospero, J. M., Baker, A. R., Dentener, F., Ickes, L., Liss, P. S., Mahowald, N. M., Nickovic, S., García-Pando, C. P., Rodríguez, S., Sarin, M., Tegen, I., and Duce, R. A.: Atmospheric Transport and Deposition of Mineral Dust to the Ocean: Implications for Research Needs, Environ. Sci. Technol., 46, 1039010404, doi:10.1021/es300073u, 2012.

Shao, Y., Wyrwoll, K.-H., Chappell, A., Huang, J., Lin, Z., McTainsh, G. H., Mikami, M., Tanaka, T. Y., Wang, X., and Yoon, S.: Dust cycle: An emerging core theme in Earth system science, Aeolian Research, 2, 181-204, doi:10.1016/j.aeolia.2011.02.001, 2011.

Sullivan, R. C., Guazzotti, S. A., Sodeman, D. A., and Prather, K. A.: Direct observations of the atmospheric processing of Asian mineral dust, Atmos. Chem. Phys., 7, 1213-1236, doi:10.5194/acp-7-1213-2007, 2007.

Taylor, K. E.: Summarizing multiple aspects of model performance in a single diagram, J. Geophys. Res., 106, 7183, doi:10.1029/2000JD900719, 2001.
Tiedtke, M.: A Comprehensive Mass Flux Scheme for $\mathrm{Cu}$ mulus Parameterization in Large-Scale Models, Mon. Weather Rev., 117, 1779-1800, doi:10.1175/15200493(1989)117<1779:ACMFSF>2.0.CO;2, 1989.

Tobo, Y., Zhang, D., Nakata, N., Yamada, M., Ogata, H., Hara, K., and Iwasaka, Y.: Hygroscopic mineral dust particles as influenced by chlorine chemistry in the marine atmosphere, Geophys. Res. Lett., 36, L05817, doi:10.1029/2008GL036883, 2009.

Tobo, Y., Zhang, D., Matsuki, A., and Iwasaka, Y.: Asian dust particles converted into aqueous droplets under remote marine atmospheric conditions, P. Natl. Acad. Sci., 107, 17905-17910, doi:10.1073/pnas.1008235107, 2010.

Tost, H., Jöckel, P., Kerkweg, A., Sander, R., and Lelieveld, J.: Technical note: A new comprehensive SCAVenging submodel for global atmospheric chemistry modelling, Atmos. Chem. Phys., 6, 565-574, doi:10.5194/acp-6-565-2006, 2006a.

Tost, H., Jöckel, P., and Lelieveld, J.: Influence of different convection parameterisations in a GCM, Atmos. Chem. Phys., 6, 54755493, doi:10.5194/acp-6-5475-2006, 2006b.

Tost, H., Jöckel, P., and Lelieveld, J.: Lightning and convection parameterisations - uncertainties in global modelling, Atmos. Chem. Phys., 7, 4553-4568, doi:10.5194/acp-7-4553-2007, 2007.

Tost, H., Lawrence, M. G., Brühl, C., Jöckel, P.: The GABRIEL Team, and The SCOUT-O3-DARWIN/ACTIVE Team: Uncertainties in atmospheric chemistry modelling due to convection parameterisations and subsequent scavenging, Atmos. Chem. Phys., 10, 1931-1951, doi:10.5194/acp-10-1931-2010, 2010.

Ussher, S. J., Achterberg, E. P., Powell, C., Baker, A. R., Jickells, T. D., Torres, R., and Worsfold, P. J.: Impact of atmospheric deposition on the contrasting iron biogeochemistry of the North and South Atlantic Ocean: SURFACE IRON IN THE ATLANTIC OCEAN, Global Biogeochem. Cy., 27, 1096-1107, doi:10.1002/gbc.20056, 2013.

van der Werf, G. R., Randerson, J. T., Giglio, L., Collatz, G. J., Mu, M., Kasibhatla, P. S., Morton, D. C., DeFries, R. S., Jin, Y., and van Leeuwen, T. T.: Global fire emissions and the contribution of deforestation, savanna, forest, agricultural, and peat fires (19972009), Atmos. Chem. Phys., 10, 11707-11735, doi:10.5194/acp10-11707-2010, 2010.

Wang, G., Cheng, C., Meng, J., Huang, Y., Li, J., and Ren, Y.: Field observation on secondary organic aerosols during Asian dust storm periods: Formation mechanism of oxalic acid and related compounds on dust surface, Atmos. Environ., 113, 169176, doi:10.1016/j.atmosenv.2015.05.013, 2015.

Winker, D. M., Hunt, W. H., and McGill, M. J.: Initial performance assessment of CALIOP, Geophys. Res. Lett., 34, L19803, doi:10.1029/2007GL030135, 2007.

Winker, D. M., Vaughan, M. A., Omar, A., Hu, Y., Powell, K. A., Liu, Z., Hunt, W. H., and Young, S. A.: Overview of the CALIPSO Mission and CALIOP Data Processing Algorithms, J. Atmos. Ocean. Tech., 26, 2310-2323, doi:10.1175/2009JTECHA1281.1, 2009.

Wong, S., Dessler, A. E., Mahowald, N. M., Colarco, P. R., and da Silva, A.: Long-term variability in Saharan dust transport and its link to North Atlantic sea surface temperature: SAHARAN DUST AND SST VARIABILITY, Geophys. Res. Lett., 35, L07812, doi:10.1029/2007GL032297, 2008. 
Wu, Z., Birmili, W., Poulain, L., Wang, Z., Merkel, M., Fahlbusch, B., van Pinxteren, D., Herrmann, H., and Wiedensohler, A.: Particle hygroscopicity during atmospheric new particle formation events: implications for the chemical species contributing to particle growth, Atmos. Chem. Phys., 13, 6637-6646, doi:10.5194/acp-13-6637-2013, 2013.

Yu, H., Chin, M., Remer, L. A., Kleidman, R. G., Bellouin, N., Bian, H., and Diehl, T.: Variability of marine aerosol finemode fraction and estimates of anthropogenic aerosol component over cloud-free oceans from the Moderate Resolution Imaging Spectroradiometer (MODIS), J. Geophys. Res., 114, D10206, doi:10.1029/2008JD010648, 2009.

Yu, H., Remer, L. A., Kahn, R. A., Chin, M., and Zhang, Y.: Satellite perspective of aerosol intercontinental transport: From qualitative tracking to quantitative characterization, Atmos. Res., 124, 73-100, doi:10.1016/j.atmosres.2012.12.013, 2013.
Yu, H., Chin, M., Bian, H., Yuan, T., Prospero, J. M., Omar, A. H., Remer, L. A., Winker, D. M., Yang, Y., Zhang, Y., and Zhang, Z.: Quantification of trans-Atlantic dust transport from seven-year (2007-2013) record of CALIPSO lidar measurements, Remote Sens. Environ., 159, 232-249, doi:10.1016/j.rse.2014.12.010, 2015.

Zhang, G. and McFarlane, N. A.: Sensitivity of climate simulations to the parameterization of cumulus convection in the Canadian climate centre general circulation model, Atmosphere-Ocean, 33, 407-446, doi:10.1080/07055900.1995.9649539, 1995. 